\title{
Role of the endocannabinoid system in drug addiction
}

Jorge Manzanares ${ }^{1,6}$, David Cabañero ${ }^{2,6}$, Nagore Puente ${ }^{3,4,6}$, María S. GarcíaGutiérrez $^{1,6}$, Pedro Grandes ${ }^{3,4,6}$, Rafael Maldonado ${ }^{2,5,6}$

${ }^{1}$ Neurociencies Institute, Miguel Hernandez University-CSIC, Avenue de Ramón y Cajal s/n, San Juan de Alicante, 03550 Alicante, Spain.

${ }^{2}$ Laboratory of Neuropharmacology, Department of Experimental and Health Sciences, Pompeu Fabra University, PRBB, C/ Doctor Aiguader 88, 08003 Barcelona, Spain.

${ }^{3}$ Department of Neurosciences, Faculty of Medicine and Nursing, University of the Basque Country UPV/EHU, E-48940 Leioa, Vizcaya, Spain.

${ }^{4}$ Achucarro Basque Center for Neuroscience, Science Park of the UPV/EHU, Leioa, Vizcaya, Spain.

${ }^{5}$ IMIM (Hospital del Mar, Medical Research Institute), Barcelona, Spain.

${ }^{6}$ Cooperative Health Research Thematic Network, Addictive Disorders Network, Heatlh Institute Carlos III, MICINN and FEDER, Madrid, Spain.

Correspondence should be addressed to:

Rafael Maldonado: Phone: +34933160824. Fax: +34933160901. E-mail address: rafael.maldonado@upf.edu Jorge Manzanares: Phone: +34965919248. E-mail address: jmanzanares@goumh.umh.es Pedro Grandes: Phone: +34 946012875. E-mail address: pedro.grandes@ehu.eus 


\section{Abstract}

Drug addiction is a chronic relapsing disorder that produces a dramatic global health burden worldwide. Not effective treatment of drug addiction is currently available probably due to the difficulties to find an appropriate target to manage this complex disease raising the needs for further identification of novel therapeutic approaches. The endocannabinoid system has been found to play a crucial role in the neurobiological substrate underlying drug addiction. Endocannabinoids and cannabinoid receptors are widely expressed in the main areas of the mesocorticolimbic system that participate in the initiation and maintenance of drug consumption and in the development of compulsion and loss of behavioral control occurring during drug addiction. The identification of the important role played by CB1 cannabinoid receptors in drug addiction encouraged the possible used of an early commercialized CB1 receptor antagonist for treating drug addiction. However, the incidence of serious psychiatric adverse events leaded to the sudden withdrawal from the market of this CB1 antagonist and all the research programs developed by pharmaceutical companies to obtain new CB1 antagonists were stopped. Currently, new research strategies are under development to target the endocannabinoid system for drug addiction avoiding these side effects, which include allosteric negative modulators of CB1 receptors and compounds targeting CB2 receptors. Recent studies showing the potential role of CB2 receptors in the addictive properties of different drugs of abuse have open a promising research opportunity to develop novel possible therapeutic approaches.

\section{Keywords}

Mesolimbic system, nucleus accumbens, prefrontal cortex, CB1 receptors, CB2 receptors, rimonabant, CB2R allosteric modulators 


\section{Introduction}

Drug addiction is a chronic relapsing disorder characterized by compulsive drug use and seeking in spite of negative consequences, loss of control over drug consumption and repeated relapse in drug use even after long periods of abstinence [1]. It is estimated that 255 million people used illicit drugs in 2015, which translates into an annual prevalence of illicit drug use of 5.3\%, being cannabis the most used [2]. However, the global burden of disease and injury caused by licit drugs is even more dramatic. Indeed, tobacco kills more than 7 million people worldwide every year, being $12 \%$ of deaths of all people aged over 30 due to tobacco, whereas 3.3 million deaths every year result from harmful use of alcohol representing $5.9 \%$ of all deaths [3]. In spite the enormous health burden worldwide of drug addiction, up to date not effective treatment is available probably due to the difficulties to find an appropriate target to manage this complex disease. Indeed, probably the most advance approach for treating drug addiction is the substitutive agonist treatment of opioid dependence [4]. However, alcohol, nicotine, cannabis, psychostimulants and other kinds of addiction are fully devoid of an effective treatment. This lack of effective treatment underlines the needs of further research to better understand the neurobiological mechanisms involved in this disease in order to identify novel therapeutic targets and to develop novel compounds for treating drug addiction. Acute administration of all the prototypical drugs of abuse including opioids, cannabinoids, psychostimulants, alcohol and nicotine, enhances the activity of the mesolimbic dopamine (DA) system [5]. All these drugs increase DA release in the nucleus accumbens (NAc) shell through stimulation of DA neurons from the ventral tegmental area (VTA), and this neurochemical response has been related to the rewarding effect of drugs of abuse [6]. These rewarding effects produce a hedonic experience that 
is crucial for the initiation and maintenance of drug consumption [7]. However, repeated exposure to drugs of abuse produce important adaptive changes leading to an attenuated release of DA in the reward circuit that has been revealed in both animals [8] and humans [9]. This attenuated DA release renders the reward system less sensitive and the addict no longer experiences the same degree of euphoria when using the drug [10].

In addition, repeated drug exposure also produces adaptive changes in the circuitry of the extended amygdala resulting in enhanced reactivity to stress and the emergence of negative emotions [11]. This "antireward" system encompasses neurotransmitters involved in the stress response, including corticotropin-releasing factor and dynorphin, and becomes overactive in the addicted brain inducing important dysphoric effects when the drug is no longer present [12]. These emotional negative consequences also play a crucial role in the maintenance of drug consumption, leading to a compulsive intake not just to obtain reward, but also to alleviate the aversive state associated with drug withdrawal.

Over the time, repeated drug exposure leads to profound impairments in decision-making that are closely related to functional and morphological changes occurring in the prefrontal cortex (PFC) [13]. The PFC plays a crucial role in executive processes including the capacities for self-regulation, behavioral control and flexibility [14]. A down-regulation of DA signaling similar to that previously described in the reward circuit also occurs in the PFC and their associated circuits after repeated drug exposure. These changes are linked to neuroplastic and morphological changes in the PFC glutamatergic neurons [10]. These alterations weaken the inhibitory control that cortical areas exert on the mesolimbic system impairing the capability to control the decisions related to drug consumption. The dysfunctions in DA reward system and stress circuits induced by the repeated drug exposure along with the major changes occurring in the cortical areas 
produce profound behavioral impairments leading to the loss of control, compulsive drug use and relapse that characterize the addicted disease.

Other neurotransmitter systems are also closely involved in the neurobiological substrate of drug addiction. One of the most widely investigated neurobiological systems in the context of drug addiction is the endocannabinoid system, which has opened interesting expectative for developing novel therapeutic approaches.

\section{Distribution of endocannabinoid components in the central nervous system}

The endocannabinoid system is widely distributed in the central and peripheral nervous system [17], and also in many other tissues [20], where it regulates brain functions by acting on different cell types and cellular compartments [17,21,22]. This system is integrated by cannabinoid receptors, endogenous ligands (endocannabinoids) (eCBs) and their synthesizing and degrading enzymes, intracellular signalling pathways as well as transport systems [15-19].

\subsection{CB1 and CB2 receptors in the central nervous system}

The CB1 receptors (CB1R) are the most abundant G protein-coupled receptors in the brain [23]. Their expression in the central nervous system (CNS) is widespread and heterogeneous and have crucial roles in regulating brain function and pathophysiological processes [17,22,24-33]. CB1R are abundant in the basal ganglia (substantia nigra reticulata, globus pallidus, striatum, entopeduncular nucleus), cortex, NAc, cerebellum and hippocampus [23,34-36]. CB1R immunoreactivity is greatly reduced in conditional mutant mice lacking CB1R mainly from GABAergic neurons (GABA-CB $1-\mathrm{KO}$ ), but less

in conditional mutant mice lacking CB1R mainly from cortical glutamatergic neurons (Glu-CB1-KO) with respect to the wild type [25,26,31,37] suggesting a predominant 
localization of CB1R in GABAergic neurons. Substantia nigra pars reticulata lacks CB1R immunoreactivity in GABA-CB1-KO, and a large decrease in $\mathrm{CB} 1 \mathrm{R}$ staining is observed in the GABA-CB $1-K O$ hippocampus but not at the glutamatergic commissural/associational synapses in the dentate molecular layer [25,26,36,37]. Furthermore, a conspicuous CB1R staining is detected in the striatum, cortex, olfactory tubercle, amygdala, hippocampus of genetic rescue mice expressing CB1R only in dorsal telencephalic glutamatergic neurons (Glu-CB $1-R S$ ) and, remarkably, in the dentate molecular layer $[22,25,38]$. In the rescue mice expressing CB1R only in GABAergic neurons (GABA-CB $-\mathrm{RS}$ ), strong $\mathrm{CB} 1 \mathrm{R}$ immunoreactivity is revealed in the cortex hippocampus, anterior olfactory nucleus, piriform cortex, globus pallidus, entopeduncular nucleus, amygdala, and substantia nigra, and moderate to strong in the striatum [22].

CB1R expression is very high in inhibitory GABAergic synaptic terminals mostly in cortical and hippocampal cholecystokinin (CCK)-positive GABAergic interneurons $[17,26,35,39-42]$, low in excitatory glutamatergic synapses $[22,25,28,38,43,44]$ and very low in brain astrocytes [33,45-49]. Brain CB1R are mostly localized in axon terminals and preterminals away from the presynaptic active zones and are also localized at mitochondria in neurons [50-54] and astrocytes [33]. Thus, CB1R were distributed in GABAergic terminals ( 56\%), glutamatergic terminals ( 12\%), astrocytes ( $\sim 6 \%$, mitochondria ( 15\%) and in other compartments ( 11\%) in the hippocampus [32,33]. In contrast, $\mathrm{CB} 2$ cannabinoid receptors (CB2R) were initially considered as the peripheral cannabinoid receptor due to its high expression in the rat spleen [55] and leukocyte subpopulation in humans [56]. Also, the first attempts to identify CB2R in CNS under basal conditions failed since it only could be detected under pathological conditions such as in senile plaques in Alzheimer's disease [57], activated microglial cells/macrophages 
in multiple sclerosis, spinal cord in amyotrophic lateral sclerosis [58] and in the vicinity of tumours [59]. However, this landscape changed dramatically in the last decade, thanks to the findings from the group of Sharkey and colleagues in 2005 [60] revealing that CB2R are expressed in neurons of the brainstem of mice, rats and ferrets under normal conditions. Since then, further studies have contributed to characterize the expression of CB2R in several brain regions including striatum, amygdala, hippocampus and the (VTA) [61-64]. Interestingly, in some of these brain regions CB2R were detected not only in microglia cells $[65,66]$ but also in neurons [64]. Some authors have not found CB2R in the intact CNS [56,67-71], but other studies have reported neuronal CB2R expression in healthy brain $[60,63,72-74]$. Nevertheless, the presence of CB2R has been described in cortical, hippocampal, pallidal and mesencephalic neurons [75], as well as in the hippocampus, frontal cortex, amygdala and striatum [61,63,74,76-78]. Furthermore, these receptors have also been identified in striatal GABAergic neurons of non-human

primates $[75,79]$ as well as in the amygdala, caudate, putamen, NAc, cortex, hippocampus and cerebellum $[80,81]$. However, the localization of CB2R in the CNS remains controversial since doubts have been raised about the specificity of CB2R antibodies [66,82]. New genetic strategies based on mouse lines expressing enhanced green fluorescent protein under the control of the $\mathrm{CB}_{2}$ promoter have been developed to circumvent this problem [71].

\subsection{Endocannabinoids in the central nervous system}

The eCBs are lipid messengers that exert their influence in a paracrine, autocrine and probably endocrine mode, because their lipid nature allows them to diffuse and cross 
membranes $[15,17,18,81-84]$. They are cannabinoid receptor agonists and constitute a family of molecules that are not accumulated in secretory vesicles but rather synthesized on demand and released right after to the extracellular space following physiological and pathological stimuli.

The two main eCBs are derivatives of polyunsatured fatty acids, Narachidonoylethanolamine (anandamide, AEA) [85] and 2-arachidonoylglycerol (2-AG), being this last endocannabinoid the most abundant in the brain [86]. The AEA precursor $\mathrm{N}$-arachidonoyl phosphatidylethanolamine (NAPE) is generated by the transfer of arachidonic acid from phosphatidylcholine to phosphatidylethanolamine by the $\mathrm{Ca}^{2+}$ dependent $\mathrm{N}$-acyltransferase $[84,87,88]$. Then, AEA synthesis is produced by the $\mathrm{N}$ acylphosphatidylethanolamine specific phospholipase D (NAPE-PLD) that hydrolyses $\mathrm{N}$-arachidonoyl phosphatidylethanolamine localized in cell membranes [84,89]. The AEA half-life is very short because of its quick uptake by a high affinity AEA membrane transporter distributed in neurons and glia [90]. AEA is inactivated by fatty acid amide hydrolase (FAAH) present in many organs and also in the brain $[84,91,92]$ at postsynaptic localization $[35,84,93]$. FAAH is a serine-hydrolase enzyme bound to intracellular membranes that catalyzes AEA into arachidonic acid and ethanolamine [88].

2-AG participates in the CB1R-dependent retrograde signalling and is an intermediate metabolite for lipid synthesis providing arachidonic acid for prostaglandin synthesis $[82,84,88]$. Neuronal membrane depolarization or the activation of Gq-coupled GPCRs triggers the synthesis of 2-AG [84]. The diacylglycerol precursors come from the hydrolysis of membrane phosphatidylinositol by phospholipase $C, \beta$ or $\delta$. The degradation of these precursors by DAGL- $\alpha$ and DAGL- $\beta$ drives 2-AG synthesis $[81,82,84,94,95]$. The DAGL $\alpha$ isoform synthesizes the greatest amount of 2-AG, whereas DAGL $\beta$ synthesizes 2-AG under certain circumstances [90]. Monoacylglycerol lipase (MAGL) is 
a serine-hydrolase enzyme mainly found in presynaptic terminals that catalyzes 2-AG into arachidonic acid and glycerol $[35,82,84,91,92]$. Also, the $\alpha / \beta$-hydrolase domain 6 (ABHD6) and domain 12 (ABHD12) degrade 2-AG [84,88].

\subsection{Functional localization of $\mathrm{CB} 1$ and $\mathrm{CB} 2$ receptors in the mesocorticolimbic} system

The expression of CB1R is medium-high in the dorsal and ventral striatum, and low in the VTA $[23,36,96]$. Dorsomedial and ventral striatal glutamatergic neurons significantly express CB1R. Indeed, the CB1R distribution in the striatum is maintained in GABA$C B_{1}-\mathrm{KO}$ mice although it is strongly reduced in Glu-CB$-\mathrm{KO}$ [36]. In VTA, CB1R immunoreactivity has been localized to both symmetric synapses of local GABAergic neurons [97-99] and to vesicular glutamate transporter-positive presynaptic terminals apposed to dendrites of DA neurons [100]. Also, CB1R co-localize with tyrosine hydroxylase (TH) demonstrating a direct regulatory role on VTA DA neurons [101]. Moreover, DAGL $\alpha$ is strongly expressed in the VTA neurons in postsynaptic TH-positive and TH-negative dendrites to excitatory and inhibitory synapses [98]. Interestingly, the postsynaptic DAGL $\alpha$ labeling is related to the presynaptic localization of CB1R suggesting a link between 2-AG synthesis and CB1R activation in the VTA [35,98].

The endocannabinoid system plays a central role in modulating DA levels in the CNS [102]. CB1R activation increases DA and decreases GABA in the medial PFC [103] and also increases DA firing of single VTA cells [104,105]. The PFC is a key player in emotional learning plasticity [106] and addictive processes [107] and the endocannbinoid system is closely involved in these physiological functions. CB1R are highly expressed in the medial PFC $[35,108,109]$ that mediates an increase in DA transmission $[110,111]$. High CB1R expression is found in large CKK-containing basket interneurons [112], 
whereas parvalbumin and somatostatin-expressing interneurons lack this receptor $[113,114]$. Low but detectable CB1R mRNA levels were revealed in the glutamatergic neurons of many cortical regions $[25,115]$. CB1R staining is noticeable in the striatum, cortex, PFC and amygdala in Glu-CB1-RS mice [22]. Furthermore, CB1R localization is mostly restricted to layers II/III and V/VI of the prelimbic PFC [116]. Presynaptic CB1R are facing postsynaptic metabotropic glutamate receptor type-5 (mGluR5) in dendritic elements that also contained DAGL $\alpha$ in the PFC [117]. This molecular arrangement is responsible for the endocannabinoid long-term depression elicited by prolonged synaptic stimulation of excitatory inputs to layers V/VI [117]. Furthermore, the vast majority of the medial PFC excitatory projections to the VTA are from prelimbic and cingular neurons that make excitatory synapses with GABAergic interneurons and also DA neurons $[118,119]$. However, the infralimbic medial PFC only sends about $10 \%$ of the PFC excitatory projections to the VTA [119]. Interestingly, the bed nucleus of stria terminalis (BNST) is a relay station of this excitatory input from the infralimbic cortex to the VTA DA neurons. The infralimbic cortical terminals in the BNST are equipped with CB1R and stimulation of these receptors inhibits the activity of VTA DA cells elicited by activation of the infralimbic cortex [120]. As to the enzymes, relatively low NAPE-PLD expression [121] and moderate DAGL $\alpha$ and DAGL $\beta$ mRNA levels have been detected in cortical regions [122]. On the other hand, FAAH immunoreactivity is observed in neuronal cell bodies and dendrites throughout cortical layers II-VI and in layer V neurons [35,93]. MAGL mRNA is more strikingly detected in layer IV, deep layer V, and in layer VI throughout the cortex [91]. Finally, the ABHD6 immunolocalization in the PFC is mostly in dendritic spines facing CB1R immunopositive terminals [123].

The basolateral amygdala contains abundant CB1R that modulate GABAergic synaptic transmission [124] and excitability [125], and is functionally involved in reward related 
memories and memory consolidation [126-128]. The CB1R expression is high in CCKpositive GABAergic synaptic terminals in basolateral amygdala [35,129] and low in glutamatergic neurons of cortical origin in this area $[25,35,129]$. Neurons in the basolateral amygdale exhibit low NAPE-PLD mRNA [121]. DAGL $\alpha$ is at postsynaptic perikaryal membranes of pyramidal neurons receiving CCK-containing axonal boutons immunopositive for CB1R and MAGL [35,129]. Furthermore, CB1R immunoreactive fibers sit around FAAH-immunoreactive neuronal cell bodies [93].

The NAc has also an important role in reinforcing addictive behaviors [130] and contains low to moderate CB1R levels and abundant DA receptors [131-133]. The CB1R are localized in excitatory PFC-NAc synaptic terminals, but not in the DA VTA-NAc, as well as in the GABAergic axon terminals of local medium-spiny neurons and parvalbuminpositive interneurons in the NAc [132,134,135]. Inhibition of GABA release by cannabinoids seems to control DA release in NAc [97,136-139]. As expected, DAGL $\alpha$ is distributed in dendritic spines and at perisynaptic positions of somatodendritic domains [135], moderate MAGL mRNA is detected in the NAc shell [91], but FAAH does not seem to be present [93].

Finally, the presence of CB2R in DA cell bodies has also been reported [64,140-143]. Hence, CB2R mRNA and protein were detected in TH-immunopositive and THimmunonegative VTA neurons [64,140-142]. Furthermore, CB2R mRNA expression increases in the VTA DA neurons, as well as in the PFC and striatum, after cocaine selfadministration. Interestingly, CB2R activation inhibits VTA DA neurons [64,140142,144] leading to a decrease in DA release in the NAc and, as a consequence, a reduction in cocaine self-administration [142]. Nevertheless, doubts have been raised with regards to the specificity of the antibodies used to detect CB2R by immunohistochemistry techniques [35]. 


\section{Role of CB1 receptors in drug addiction}

CB1R and its endogenous ligands are expressed through the mesocorticolimbic pathway and also in the brain regions involved in decision-making, withdrawal symptoms and relapse [145,146]. This distribution makes CB1R essential for the establishment of addiction to cannabinoid drugs, and is also crucial for the neurobehavioral processes triggered by any of the prototypical drugs of abuse.

\subsection{Involvement of $\mathrm{CB} 1$ receptors in drug rewarding properties}

One of the principal substrates of the rewarding effect of drugs of abuse is the mesocorticolimbic pathway, which consists of DA neurons from the ventral tegmental area (VTA) that send projections to the NAc and other areas of the limbic forebrain. In the VTA, glutamatergic and GABAergic terminals synapse with the DA neurons and CB1R are expressed presynaptically to control neurotransmitter release. GABAergic transmission inhibits DA neurons and limits the reward sensation, and presynaptic CB1R in these synapses inhibit GABA release, improving disinhibition and promoting reward. On the contrary, glutamatergic signaling activates DA neurons and induces long-term potentiation associated with the hedonic responses [146]. Thus, in glutamatergic synapses, postsynaptic eCBs act retrogradely on presynaptic CB1R limiting DA release. However, the predominant tone is GABAergic and acute administration of CB1R agonists induces disinhibition and reward, although these effects are highly dose-sensitive and may shift to negative reinforcing effects as doses increase [147]. Through this presynaptic control, CB1R in the VTA modulate the DA efflux in the NAc elicited by cannabinoid drugs, but also the increases in DA observed after other prototypical drugs of abuse such as morphine, nicotine and ethanol [147]. Indeed, genetic and 
pharmacological blockade of CB1R abolished drug-induced DA increases in rodents treated with $\Delta 9$-tetrahydrocannabinol (THC), nicotine, heroin, morphine or ethanol [148151]. The consequences of CB1R control were demonstrated in animal models of reward showing that CB1R agonists enhance conditioned place preference. Rodents treated with CB1R agonists displayed increased preference for contexts associated with nicotine [152] and ethanol [153,154], although the results obtained with morphine or heroin were contradictory [155]. On the contrary, conditioned place preference experiments in CB1R knockout mice showed a reduction of nicotine place preference [156] and ethanolassociated contexts [157], and mixed results were obtained in morphine-treated mice $[155,158]$. However, the treatment with the CB1R antagonist rimonabant decreased conditioned place preference for morphine, heroin, ethanol and nicotine, suggesting an effect CB1R on primary reward-associated memories. On the other hand, drug selfadministration experiments where animals freely operate a lever to self-administer drug also showed inhibition of this operant behavior when CB1R activity was inhibited, either pharmacologically or genetically. This effect was observed for all the drugs mentioned above, including morphine [159], heroin [160], ethanol [161] and nicotine [149]. Hence, CB1R seem essential for the reinforcing and motivational properties of these drugs of abuse, and are involved in the execution of the operant behavior that promotes its consumption.

Psychostimulant drugs such as cocaine, methamphetamine or MDMA have a different mechanism of action to induce reward, since they produce their effects through direct modulation of monoamine transporters in the DA terminals [162]. Thus, targeting VTA CB1R did not affect the DA release induced by these drugs because they act directly on the NAc terminals [151,157,163,164]. Indeed, mice lacking CB1R maintained conditioned place preference induced by cocaine and MDMA [157,164,165]. Other 
studies showed that treatment with rimonabant impaired conditioned place preference to these psychostimulant drugs, however the doses of psychostimulants were lower than in the studies using knockout mice [166-168], suggesting that high cocaine doses could circumvent the modulatory function of the endocannabinoid system. Studies using drug self-administration paradigms have yielded mixed results in CB1R knockout mice, with attenuation of drug-taking behavior [151,164] or no change in restrained mice [169]. Interestingly, treatment with CB1R agonists decreased self-administration of cocaine $[170,171]$ and MDMA [172], an effect that could be related to a decrease in the dose needed to obtain reward when CB1R agonists are co-administered. Alternatively, CB1R of PFC neurons have shown effect reducing DA outflow in the NAc, which could explain an effect of CB1R constraining reward in certain experimental conditions[173]. Rimonabant treatment lacked effect on operant responding for cocaine under fixed-ratio schedules of reinforcement once drug-taking behavior was established [163,174,175]. However, it decreased self-administration in progressive ratio schedules where mice are required to increase the number or operant responses to obtain new drug doses [149,151], which suggests a role of CB1R in the motivation to obtain the psychostimulant. While the lack of effect on psychostimulant-induced DA release may indicate that CB1R activity is not related to the basic rewarding response to psychostimulants, they seem relevant for the conscious and repetitive operant behavior associated with the motivation of the animal for the drug. This complex activity involves reward and the association of operant behavior with expectations and hedonic or relieving responses, and is favored by a shift from goal-directed to habitual behaviors. Recent studies highlight the participation of CB1R-expressing orbitofrontal neurons in the control of decision-making [176]. CB1R are expressed in these neurons and in the dorsal striatum, an area that receives orbitofrontal projections. There, CB1R activity favors the shift from goal-directed to 
habitual behaviors, impairing decision-making and facilitating repetitive drug intake [176,177]. Thus, targeting CB1R has been suggested as an efficient strategy to improve decision-making and facilitate goal-directed behaviors.

\subsection{Involvement of $\mathrm{CB1}$ receptors in the negative aspects of withdrawal}

During drug addiction, somatic signs of withdrawal may appear, accompanied by anxiety, cognitive impairment and a generalized state of negative affect that promote compulsive drug-seeking [178]. Rimonabant precipitated somatic signs of abstinence in morphinedependent animals and CB1R knockout mice showed attenuation of ethanol and naloxone-precipitated morphine withdrawal, depicting the reciprocal modulation of the cannabinoid and the opioid systems $[179,180]$. On the contrary, genetic deletion of CB1R did not modify the somatic manifestations of nicotine withdrawal [156]. Therefore, the participation on physical withdrawal may depend on the specific mechanism of action of the drug.

The involvement of CB1R in affective responses is highlighted in studies showing the enhanced aggressiveness, anxiety and depressive-like behavior of CB1R knockout mice [158,181]. Acute moderate doses of cannabinoids can be either anxiogenic [182] or anxiolytic [183-185], probably depending on the drug and the specific context. Interestingly, CB1R agonists showed anxiolytic-like effects in mice chronically treated with psychostimulants [186] or nicotine [187]. However, repeated treatments and high doses of cannabinoid agonists trigger negative emotionality in humans and animals, which promotes drug consumption [181,188,189]. Furthermore, the effects of stressfullike stimuli promoting ethanol-taking behavior are mediated through CB1R in mice subjected to a model of ethanol dependence [190]. Altogether, CB1R seem to play an 
important function modulating affective behaviors and could be relevant in the response of addict individuals to stressful situations [191].

Furthermore, exposure to drugs of abuse involves formation of memories associated to drug reward and to drug withdrawal. These memories are highly relevant for drug and cue-induced reinstatement of drug-taking behavior, and CB1R have shown a prominent participation on extinction of aversive and contextual memory [24,192]. Indeed, mice lacking CB1R showed an improvement of long-term memory associated with an impairment of long-term potentiation in hippocampal synapses [193]. In this context, CB1R agonists facilitated relapse of alcohol, nicotine, heroin and cocaine-seeking behavior in abstinent animals, whereas CB1R antagonists attenuated cue and druginduced reinstatement $[175,194-196]$. Thus, a pronounced CB1R activity may inhibit the memory processes associated to drug withdrawal, whereas CB1R antagonists could be effective enhancing these negative memories and limiting drug intake and relapse. NAc, amygdala and PFC seem to modulate these motivational aspects that can drive drug relapse $[24,197,198]$. Thus, CB1R activity modulates almost every neurobehavioral processes involved in drug addiction, and would represent an appropriate target to limit drug abuse or favor rehabilitation.

\subsection{Targeting CB1 receptor for the treatment of drug addiction}

The crucial role of CB1R in the addictive properties of all the prototypical drugs of abuse suggests a potential interest of CB1R antagonists for treating drug addiction. Indeed, several clinical trials have demonstrated the effectiveness of the CB1R antagonist rimonabant to obtain smoking cessation [199] and preliminary clinical results suggest the efficacy of this CB1R antagonist for treating alcohol dependence [200]. Interestingly, this 
efficacy of Rimonabant was dependent on a genetic polymorphism of the dopamine receptor D2 gene (DRD2)[201]. Rimonabant was approved by the European authorities for the treatment of obesity [202], and it was commercialized in Europe and several countries worldwide from 2006 to 2008. However, the incidence of serious psychiatric adverse events, such as anxiety, depression and suicidal ideation, leads to the sudden withdrawal of rimonabant in 2008 [203]. At that moment, all the research programs that were developed by multiple pharmaceutical companies to obtain new CB1R antagonists were immediately stopped excepting a specific clinical trial to treat liver steatosis [204] that did not achieve the final approval for this indication. Among the different reasons for the failure of rimonabant, the inverse agonist properties of this orthosteric antagonist could account for the appearance of these serious psychiatric side effects. The clinical use of a unique elevated dose of rimonabant (20 mg) that has a very long half-life in humans may also favor the incidence of these central side effects. In addition, obese patients exposed to weight loss therapies are particularly sensitive to emotional disorders and this fact was not taken into consideration in the recruitment of patients to be treated with rimonabant. .

Several strategies to target CB1R in a different manner than a complete orthosteric antagonism were initiated after rimonabant withdrawal. The development of neutral antagonists devoid of inverse agonism activity was an approach investigated by several research groups [205] without achieving at the present moment any successful compound of interest for the development of novel clinical trials.

CB1R antagonists unable to cross the blood brain barrier were also investigated in order to obtain the peripheral metabolic effects avoiding the psychiatric side effects associated to the blockade of CB1R at the level of the CNS [206]. However, this experimental approach cannot be used for treating drug addiction since central CB1R must be targeted 
for such therapeutic purpose. Even more, peripheral CB1R blockade did not show the same efficacy than the full antagonists for treating obesity [207]. This represents an additional limitation for successfully achieving this approach since it was not effective in a disease such as obesity where peripheral CB1R should play a much more important role than in drug addiction.

A possible alternative strategy to reduce the activity of $\mathrm{CB} 1 \mathrm{R}$, that is currently investigated, consists in reducing eCBs levels. In this sense, several inhibitors of DAGL, the enzyme involved in the synthesis of 2-AG, have been developed with the purpose of decreasing the endogenous levels of this lipid that constitutes the most abundant endocannabinoid in the CNS [208]. Also, dietary manipulations to modify the phospholipid precursors responsible of the biosynthesis of endocannabinoids have been proposed to reduce the endocannabinoid tone. Indeed, dietary n-3 polyunsaturated fatty acids have been reported to reduce eCBs levels, although this effect has been mainly reported in peripheral tissues [209].

Novel endogenous allosteric negative modulators of CB1R activity have been recently identified[210]. Indeed, the endogenous steroid pregnenolone has been reported to act as a signaling specific inhibitor of the CB1R, reducing THC-induced ERK1/2 phosphorylation without modifying the effects on the cAMP pathway. Furthermore, CB1R stimulation increases brain pregnenolone levels, which in turn exerts a negative feedback on the activity of the CB1R antagonizing most of the known behavioral and somatic effects of THC. Pregnenolone acts as a signaling specific negative allosteric modulator binding to a site distinct from that occupied by orthosteric ligands. This negative feedback mediated by pregnenolone represents a loop protecting the brain from CB1R over-activation that has open novel therapeutic approaches. This biased allosteric modulation of CB1R provides a novel research strategy to decrease CB1R activity 
avoiding the classical side effects related to the orthosteric blockade of these receptors. A preliminar clinical study investigated the effects of a pregnenolone treatment on marijuana craving, but the results posted show that both pregnenolone and placebotreated groups failed to develop craving symptomatology [211]. However, pregnenolone is a precursor of other steroids, which could represent a limitation for its possible therapeutic use. The possibility to develop pregnenolone derivatives unable to generate other active steroids constitutes a promising approach to exert a negative bias modulation of CB1R avoiding the previously reported side effects, which could be of potential interest for treating drug addiction.

\subsection{Current status of medical use agents and future perspectives}

The interest of CB1R antagonists/inverse agonists in the pharmacotherapy of substance use disorders has been underlined in the previous sections. The main interest of these ligands relied on preclinical data showing the efficacy of CB1R inverse agonists/antagonists to inhibit drug-taking behaviour in operant behavioural models that mimic drug consumption in substance use disorders (Section 3.2). This effect is associated with loss of dopamine efflux and reward in drugs that evoke dopamine release through modulation of VTA DA neurons (morphine, THC, ethanol, nicotine), whereas in psychostimulant drugs the effect is DA-independent and related with blunted motivation for the drug. One additional interest of disrupting CB1R activity is the inhibition of the shift from goal-directed to habitual behaviors [176], a common behavioral pattern during substance use disorders that participates in the loss of control over drug intake [212]. The anorectic effects of CB1R blockade could also be of interest in therapy for tobacco or cocaine cessation, since weight gain causes distress in these cases, facilitating direct rejection of the treatment $[213,214]$. In spite of the efficacy of rimonabant demonstrated 
in clinical trials targeting smoking cessation and alcohol dependence $[199,200]$, the important psychiatric adverse effects associated to rimonabant treatment leads to its withdrawal from the market, the loss of interest for these classical orthosteric antagonists, and the research of the novel strategies to modulate CB1R activity exposed in the previous section.

Although CB1R antagonists are currently not available for clinical purposes, several CB1R agonists have been approved by the regulatory agencies in multiple countries including Europe and USA. Indeed, four different cannabinoid-based medicines have been approved by the European Medicines Agency (EMA) and/or the United States Food and Drug Administration (FDA): Dronabinol (Marinol ${ }^{\mathrm{R}}$ and Syndros ${ }^{\mathrm{R}}$ ), Nabilone $\left(\right.$ Cesamet $^{\mathrm{R}}$ and Canemes ${ }^{\mathrm{R}}$ ), Nabiximols $\left(\right.$ Sativex $\left.^{\mathrm{R}}\right)[215]$ and more recently cannabidiol (CBD) $\left(\right.$ Epidiolex $^{\mathrm{R}}$ ) (FDA, 2018). Dronabinol is manufactured as oral capsules or oral solution containing synthetic THC and the main indications are nausea and vomiting due to cancer chemotherapy as well as anorexia associated with weight loss in Acquired Immunodeficiency Syndrome patients. Nabilone is formulated in oral capsules containing a synthetic cannabinoid similar to THC and its main indication is nausea and vomiting associated with cancer chemotherapy. Nabiximols is commercialized as an oromucosal spray containing a similar amount of THC and CBD obtained from extracts of Cannabis sativa. The most common indication of nabiximols is the spasticity associated to multiple sclerosis, and several countries have also authorized its use for neuropathic pain in multiple sclerosis patients. The therapeutic effects of Dronabinol, Nabilone and Nabiximols have been related to the activation of CB1R, although the presence of CBD in nabiximols seems to play an important role for improving the effectiveness and minimizing the psychoactive effects of the formulation. CBD has been very recently approved by FDA (25 $5^{\text {th }}$ June, 2018) for the treatment of seizures associated with two 
paediatric rare diseases, Dravet syndrome and Lennox-Gastaut syndrome. However, the mechanisms involved in these CBD therapeutic effect remains to be fully clarified.

Another approach to target the endocannabinoid system avoiding the central side effects is the development of compounds selectively acting on CB2R that are devoid of such undesirable effects and these receptors also seem involved in the addictive properties of various prototypical drugs.

\section{Role of CB2 receptors in drug addiction}

A great deal of research has been focused in the study of the role of CB2R in the central and peripheral nervous system. The expression of CB2R is located in brain regions belonging to classical neuronal circuits involved in drug addiction, such as the VTA, NAc, amygdala and hippocampus which promotes studies to understand further its potential role in these pathological conditions. In this section, we detailed the growing evidences suggesting that CB2R present a pivotal role in addictive behaviors, including cocaine, ethanol and nicotine addiction.

\subsection{Role of $\mathrm{CB} 2$ receptors in cocaine addiction}

Converging evidences support the involvement of CB2R in different aspects related with cocaine addiction. On the one hand, genetic studies indicated that CB2R play a relevant role in cocaine motor sensitization. Mice overexpressing $\mathrm{CB} 2 \mathrm{R}$ in the $\left(\mathrm{CB}_{2} \mathrm{xP}\right)$ displayed less hyperlocomotor effects to the acute administration of cocaine and were less vulnerable to the motor sensitization induced by the repeated administration of cocaine [216]. Interestingly, opposite effects were observed in mice lacking the CB2R (CB2-/-), which presents enhanced sensitivity to cocaine-induced hyperlocomotion [217].

Conversely, pharmacological studies revealed that the administration, both systemic and locally into the NAc, of the selective CB2R agonist JWH133 blocked cocaine 
hyperlocomotion in mice [144]. Interestingly, this effect was observed in CB1-/knockout mice but disappeared in CB2-/- mice, demonstrating the involvement of CB2R in these effects of JWH133 [144]. However, in another study [218] the administration of the cannabinoid CB2R antagonist, AM630, failed to modify the locomotor effects induced by acute or repeated administration of cocaine in rats. Even so, AM630 reversed the cocaine-induced alterations in cell proliferation including neurogenic, apoptotic and gliosis processes [218].

Besides, CB2R appear to be involved in the reinforcing properties of cocaine since cocaine induced place aversion instead of place preference in CB2xP mice, and these transgenic mice present an impairment in the acquisition of cocaine self-administration [216]. Conversely, intranasal or intra-accumbens local administration of JWH133 inhibited intravenous cocaine self-administration [144]. In addition, the administration of the cannabinoid CB2R antagonist SR144528 before the priming doses of cocaine significantly reduced the reinstatement of cocaine seeking behavior in mice [219]. In contrast, the blockade of CB2R did not modify contextual memories associated with cocaine seeking in which CB1R appear to play a relevant role [219].

Additional research also supports the involvement of CB2R in cocaine addiction. Thus, repeated administration of cocaine significantly increased CB2R gene expression in mouse brain preparations[77]. Besides, in vivo studies demonstrated that repeated cocaine administered reduced CB2R protein expression in the PFC of Sprague-Dawley rats only during adolescence (PND33-39) without any alteration in the hippocampus nor in any brain region analyzed in the adulthood[220]. On the contrary, CB2R immunoreactivity decreased in Lewis and Fischer 344 rats exposed to cocaine self-administration[221]. The differences between these studies may be due to (1) the strain of rats used (SpragueDawley, Lewis and Fischer 344), (2) the doses and the pattern of cocaine administration, 
(3) the technique used (western blot vs immunohistochemistry), and (4) the time elapse between cocaine exposure and samples collection (25 days vs $24 \mathrm{~h}$ after the last selfadministration session).

All these data support the fact that CB2R modulate cocaine reward, seeking behavior and locomotor-stimulating effects. However, future studies are necessary to further explore the exact role of $\mathrm{CB} 2 \mathrm{R}$ in the different aspects of cocaine addiction

\subsection{Role of CB2 receptors in alcohol addiction}

Several studies revealed the implication of $\mathrm{CB} 2 \mathrm{R}$ in the modulation of alcohol consumption and reward. Up to date, two studies were carried out to evaluate the response of CB2-/- mice under different models of alcohol consumption. A first study demonstrated that CB2-/- mice showed high vulnerability to the pharmacological effects of single doses of ethanol [222]. It was also demonstrated that CB2-/- mice presented increased voluntary ethanol consumption in the two-bottle paradigm and motivation to drink in the oral ethanol self-administration [222]. Accordingly, the administration of the cannabinoid CB2R-agonist beta-caryophyllene reduced ethanol conditioned place preference and ethanol consumption in mice [223]. Interestingly a significant incidence of the single nucleotide polymorphism in the CNR2 gene locus, R63Q, was found, in a cohort of japanese alcoholic patients [224]. This single nucleotide polymorphism leads to a missense mutation in the first intracellular domain, resulting in a decreased cellular response to ligands of CB2R.

More recently, a potential close relationship has been reported between CB2R, stress and alcohol consumption [225]. Indeed, CB2R seems necessary to deal with stress situations that significantly increase ethanol intake. In line with this, previous studies reported that $\mathrm{CB}_{2 \mathrm{xP}}$ mice presented reduced anxiety-like behavior and modified reaction to stress, also 
supporting an involvement of CB2R in the regulation of stress responses[62]. Moreover, sub-chronic administration of the cannabinoid CB2R-agonist JWH015 increased alcohol consumption only in mice previously exposed to chronic stress without any effect under non-stressed conditions [224]. Consistent with these results, a downregulation of CB2R, CB1R and MAGL has been detected in the amygdala [226] and striatum [227] of rats exposed to repeated ethanol withdrawal.

Altogether, these results establish an important starting point for follow-up basic and clinical studies to clarify the therapeutic utility of CB2R pharmacological modulation in alcohol dependence.

\subsection{Role of $\mathrm{CB} 2$ receptors in nicotine addiction}

Only few studies have evaluated the role of CB2R in nicotine addiction. Genetic studies revealed that the absence of CB2R attenuated the rewarding effects of nicotine in the conditioned place preference and nicotine reinforcing effects in the self-administration paradigm in mice [228]. Besides, CB2R appear to play a significant role in nicotine withdrawal syndrome since CB2-/- mice showed less somatic signs associated with this withdrawal [228].

However, controversial results were obtained in pharmacological studies. The pharmacological blockade of CB2R by the selective antagonist AM630 decreased nicotine rewarding effects as previously described in CB2-/- mice [228]. On the contrary, AM630 did not modify nicotine self-administration and reinstatement of nicotine seeking in rats [229]. These discrepancies may be due, to: (1) the species of animals (rats vs mice), (2) the different experimental conditions for nicotine self-administration and (3) the doses of AM630 employed. Interestingly, the CB2R receptor agonist O-1966 given in combination with nicotine induced conditioned place preference [230]. 
Future studies will allow elucidating most of the relevant questions that are still unanswered about the role of CB2R in nicotine addictive properties.

\subsection{Mechanisms underlying the modulatory effects of CB2R on drug-addiction}

Many efforts have been made to clarify the neurobiological mechanisms by which CB2R could display its effects on drug-addiction. Most of the evidences obtained support a close interaction between CB2R and DA system, one of the main modulators of drug-reward. Indeed, the pharmacological and genetic manipulation of CB2R modify key elements of DA system including DA extracellular levels, DA receptors and the synthesizing enzyme TH. Opposite effects on DA extracellular levels in the NAc were observed after the pharmacological activation or blockade of CB2R [144]. While CB2R activation reduced the enhancement of extracellular DA levels in the NAc induced by cocaine, the blockade of CB2Rr elevated basal extracellular DA levels in the NAc. On the contrary, genetic studies did not reveal any significant difference in the extracellular levels of DA in the NAc between CB2xP and their corresponding wild type controls [216]. It is important to take into account that wild-type mice treated with CB2R agonists are not necessarily equivalent to CB2xP from the behavioral and neurochemical point of view [216].

Although CB2R were found in neurons expressing DA $\mathrm{D}_{2}$ receptors (D2R) in the NAc and VTA [216], future studies are needed to determine a possible functional cooperation between the CB2R and D2R. In support of this hypothesis, endocannabinoids have been reported to modify DA modulation of excitatory currents in the striatum controlled by the expression of D1R or D2R [231], suggesting that activation of postsynaptic DA receptors controls endocannabinoid mobilization. Interestingly, confocal microscopy images revealed that CB2R localized with key targets of nicotine addiction, the nicotine 
acetylcholine receptors containing alpha-3 and alpha-4 subunits ( $\alpha 3$ - and $\alpha 4$-nAChRs) $[232,233]$.

Finally, alterations in key elements of the DA system as well as in opioid and nicotine receptors were observed in mice with genetic modifications of CB2R. CB2-/- mice presented reduced $\mathrm{TH}$ and mu opioid receptor gene expression in the VTA and NAc, respectively [222,228]. Also, CB2-/- mice presented reduced $\alpha 3$ - and $\alpha 4-n A C h R s$ gene expression levels in the VTA [228]. Interestingly, CB2xP mice presented higher TH and DA reuptake transporter gene expression in the VTA and lower mu opioid receptor gene expression in NAc [216].

These data encouraged the development of future studies to further deepening in the neurobiological mechanisms underpinning CB2R role in brain reward circuits.

\subsection{Current status of medical use agents and future perspectives}

Although CB1R activation has been proposed as the main key target for drug addiction, CB2R also appear to play an important role in certain properties of cannabinoids (for review [234]) and could certainly represent an interesting target to develop novel pharmacological strategies to optimize the therapeutic effects and minimize the occurrence of adverse events of cannabinoid therapy. One of that promising strategy is the use of drugs acting directly over CB2R without activating CB1R. As we described here, the direct modulation of CB2R with agonists or antagonists significantly modified different aspects involved in drug addiction. Pharmacological modulation of CB2R also displayed anxiolytic [235] and antidepressant-like effects [62] along with antiinflammatory [236-238] and neuroprotective [239] properties that would be of interest for the treatment of substance use disorders. However, none of the synthetic CB2R agonists available to date reached an advanced phase of clinical development. Besides, 
these drugs presented a narrow therapeutic range above which were also able to activate CB1R [234]. In this respect, CB2R allosteric modulators, able to modulate CB2R function by interacting with allosteric sites, may result promising therapeutic tools. Due to that, these compounds provide a greater subtype selectivity [240]. Another important advantage of allosteric modulators is the selectivity of the responses that would be limited to only those tissues where eCBs are present [240]. These CB2R allosteric modulators could represent an important advance for the clinical development of cannabinoid therapy.

\section{Concluding remarks}

Multiple studies have recognized the crucial role of the endocannabinoid system in the neurobiological substrate underlying drug addiction. Early studies have identified the important role of CB1R in modulating the rewarding effects of all the prototypical drugs of abuse underlying the potential interest of this particular target of the endocannabinoid system to develop new approaches for treating drug addiction. However, the serious psychiatric adverse events associated to the blockade of CB1R in the CNS lead to prompt withdrawal from the market of rimonabant, the unique CB1R antagonist commercialized. In spite of this failure of rimonabant, the CB1R still represents an excellent target for the development of novel compounds for treating drug addiction, although other strategies different to the development of complete orthosteric antagonists have been now undertaken. The recent development of allosteric signaling-specific negative modulators of CB1R provides a promising research strategy to decrease CB1R activity avoiding the classical side effects related to the orthosteric antagonists. Recent findings revealing a potential role of CB2R in the addictive properties of different drugs of abuse have also open an interesting research opportunity to develop novel possible therapeutic approaches, including CB2R allosteric modulators. The endocannabinoid system 
certainly constitutes an excellent source of new possible therapeutic targets for multiple diseases including drug addiction. The initial failure on the development of CB1R antagonists should not discourage the public and private laboratories to continuous research in this promising topic in order to identify the most appropriate way to target the endocannabinoid system for treating CNS disorders.

\section{ACKNOWLEDGMENTS}

We acknowledge the financial support of the Spanish MINECO (\#SAF2017-84060-RAEI/FEDER-UE), Instituto de Salud Carlos III-RETICS (\#\#RD16/0017/0020), Ministerio de Sanidad, Servicios Sociales e Igualdad-Plan Nacional Sobre Drogas (\#PNSD-2017I068), and the Generalitat de Catalunya-AGAUR ((\#2017-SGR-669 and \#ICREA Acadèmia2015) and the European Commission-DG RTD (\#FP7-HEALTH-F22013-602891-NeuroPain) to RM. FEDER funding support is also acknowledged. This work was supported by Red de Trastornos Adictivos, Instituto de Salud Carlos III (ISCIII) and European Regional Development Funds-European Union (ERDF-EU) (RD16/0017/0012), The Basque Government (BCG IT764-13) and MINECO/FEDER, UE (SAF2015-65034-R) to PG. This research was supported by Instituto de Salud Carlos III (RETICS, RD12/0028/0019, RD16/0017/0014 and RD06/0001/1004), Plan Nacional Sobre Drogas (PNSD 2016/016 and 2007/061), Ministerio de Economía y Competitividad (FIS, PI14/00438) and Ministerio de Ciencia e Innovación (SAF200801106) to JM.

\section{FINANTIAL DISCLOSURES}

None of the authors reported biomedical financial interests or potential conflicts of interest. 


\section{REFERENCES}

[1] A.P. Association, Diagnostic and Statistical Manual of Mental Disorders (DSMV), 5th ed., Washington D.C., 2013.

[2] U.N.O. on D. and Crime, World Drug Report 2017, Vienna, 2017.

[3] W.H. Organisation, WHO, (n.d.). www.who.int.

[4] D.M. Novick, E.A. Salsitz, H. Joseph, M.J. Kreek, Methadone Medical Maintenance: An Early 21st-Century Perspective., J. Addict. Dis. 34 (2015) 22637. doi:10.1080/10550887.2015.1059225.

[5] R. Maldonado, The neurobiology of addiction., J. Neural Transm. Suppl. (2003) 1-14. http://www.ncbi.nlm.nih.gov/pubmed/14582800 (accessed July 2, 2018).

[6] G. Di Chiara, V. Bassareo, S. Fenu, M.A. De Luca, L. Spina, C. Cadoni, E. Acquas, E. Carboni, V. Valentini, D. Lecca, Dopamine and drug addiction: the nucleus accumbens shell connection., Neuropharmacology. 47 Suppl 1 (2004) 227-41. doi:10.1016/j.neuropharm.2004.06.032.

[7] G.F. Koob, N.D. Volkow, Neurobiology of addiction: a neurocircuitry analysis, The Lancet Psychiatry. 3 (2016) 760-773. doi:10.1016/S2215-0366(16)00104-8.

[8] Y. Zhang, S.D. Schlussman, J. Rabkin, E.R. Butelman, A. Ho, M.J. Kreek, Chronic escalating cocaine exposure, abstinence/withdrawal, and chronic reexposure: effects on striatal dopamine and opioid systems in C57BL/6J mice., Neuropharmacology. 67 (2013) 259-66. doi:10.1016/j.neuropharm.2012.10.015.

[9] N.D. Volkow, G.J. Wang, J.S. Fowler, J. Logan, S.J. Gatley, R. Hitzemann, A.D. Chen, S.L. Dewey, N. Pappas, Decreased striatal dopaminergic responsiveness in detoxified cocaine-dependent subjects., Nature. 386 (1997) 830-3. doi:10.1038/386830a0.

[10] N.D. Volkow, G.F. Koob, A.T. McLellan, Neurobiologic Advances from the Brain Disease Model of Addiction., N. Engl. J. Med. 374 (2016) 363-71. doi:10.1056/NEJMra1511480.

[11] J.H. Jennings, D.R. Sparta, A.M. Stamatakis, R.L. Ung, K.E. Pleil, T.L. Kash, G.D. Stuber, Distinct extended amygdala circuits for divergent motivational states., Nature. 496 (2013) 224-8. doi:10.1038/nature12041.

[12] G.F. Koob, M. Le Moal, Plasticity of reward neurocircuitry and the "dark side" of drug addiction., Nat. Neurosci. 8 (2005) 1442-4. doi:10.1038/nn1105-1442.

[13] D. Belin, A. Belin-Rauscent, J.E. Murray, B.J. Everitt, Addiction: failure of control over maladaptive incentive habits, Curr. Opin. Neurobiol. 23 (2013) 564572. doi:10.1016/j.conb.2013.01.025.

[14] R.Z. Goldstein, N.D. Volkow, Dysfunction of the prefrontal cortex in addiction: neuroimaging findings and clinical implications., Nat. Rev. Neurosci. 12 (2011) 652-69. doi:10.1038/nrn3119.

[15] D. Piomelli, The molecular logic of endocannabinoid signalling., Nat. Rev. Neurosci. 4 (2003) 873-84. doi:10.1038/nrn1247.

[16] D. Piomelli, More surprises lying ahead. The endocannabinoids keep us guessing., Neuropharmacology. 76 Pt B (2014) 228-34. doi:10.1016/j.neuropharm.2013.07.026.

[17] I. Katona, T.F. Freund, Multiple functions of endocannabinoid signaling in the brain., Annu. Rev. Neurosci. 35 (2012) 529-58. doi:10.1146/annurev-neuro062111-150420.

[18] B. Lutz, G. Marsicano, R. Maldonado, C.J. Hillard, The endocannabinoid system in guarding against fear, anxiety and stress., Nat. Rev. Neurosci. 16 (2015) 70518. doi:10.1038/nrn4036. 
[19] R.G. Pertwee, Endocannabinoids and Their Pharmacological Actions, in: Handb. Exp. Pharmacol., 2015: pp. 1-37. doi:10.1007/978-3-319-20825-1_1.

[20] P.V. Piazza, D. Cota, G. Marsicano, The CB1 Receptor as the Cornerstone of Exostasis, Neuron. 93 (2017) 1252-1274. doi:10.1016/j.neuron.2017.02.002.

[21] A. Busquets-Garcia, J. Bains, G. Marsicano, CB1 Receptor Signaling in the Brain: Extracting Specificity from Ubiquity., Neuropsychopharmacology. 43 (2018) 4-20. doi:10.1038/npp.2017.206.

[22] A. Gutiérrez-Rodríguez, N. Puente, I. Elezgarai, S. Ruehle, B. Lutz, L. Reguero, I. Gerrikagoitia, G. Marsicano, P. Grandes, Anatomical characterization of the cannabinoid CB 1 receptor in cell-type-specific mutant mouse rescue models, J. Comp. Neurol. 525 (2017) 302-318. doi:10.1002/cne.24066.

[23] K. Tsou, S. Brown, M.C. Sañudo-Peña, K. Mackie, J.M. Walker, Immunohistochemical distribution of cannabinoid CB1 receptors in the rat central nervous system., Neuroscience. 83 (1998) 393-411.

[24] G. Marsicano, C.T. Wotjak, S.C. Azad, T. Bisogno, G. Rammes, M.G. Cascio, H. Hermann, J. Tang, C. Hofmann, W. Zieglgänsberger, V. Di Marzo, B. Lutz, The endogenous cannabinoid system controls extinction of aversive memories., Nature. 418 (2002) 530-4. doi:10.1038/nature00839.

[25] K. Monory, F. Massa, M. Egertová, M. Eder, H. Blaudzun, R. Westenbroek, W. Kelsch, W. Jacob, R. Marsch, M. Ekker, J. Long, J.L. Rubenstein, S. Goebbels, K.-A. Nave, M. During, M. Klugmann, B. Wölfel, H.-U. Dodt, W. Zieglgänsberger, C.T. Wotjak, K. Mackie, M.R. Elphick, G. Marsicano, B. Lutz, The endocannabinoid system controls key epileptogenic circuits in the hippocampus., Neuron. 51 (2006) 455-66. doi:10.1016/j.neuron.2006.07.006.

[26] G. Marsicano, R. Kuner, Anatomical Distribution of Receptors, Ligands and Enzymes in the Brain and in the Spinal Cord: Circuitries and Neurochemistry., in: Köfalvi A. (Ed.), Cannabinoids and the Brain, Springer, Boston, MA, 2008. doi:https://doi.org/10.1007/978-0-387-74349-3_10.

[27] L. Bellocchio, P. Lafenêtre, A. Cannich, D. Cota, N. Puente, P. Grandes, F. Chaouloff, P.V. Piazza, G. Marsicano, Bimodal control of stimulated food intake by the endocannabinoid system., Nat. Neurosci. 13 (2010) 281-3. doi:10.1038/nn.2494.

[28] N. Puente, Y. Cui, O. Lassalle, M. Lafourcade, F. Georges, L. Venance, P. Grandes, O.J. Manzoni, Polymodal activation of the endocannabinoid system in the extended amygdala., Nat. Neurosci. 14 (2011) 1542-7. doi:10.1038/nn.2974.

[29] E. Soria-Gómez, L. Bellocchio, L. Reguero, G. Lepousez, C. Martin, M. Bendahmane, S. Ruehle, F. Remmers, T. Desprez, I. Matias, T. Wiesner, A. Cannich, A. Nissant, A. Wadleigh, H.-C. Pape, A.P. Chiarlone, C. Quarta, D. Verrier, P. Vincent, F. Massa, B. Lutz, M. Guzmán, H. Gurden, G. Ferreira, P.M. Lledo, P. Grandes, G. Marsicano, The endocannabinoid system controls food intake via olfactory processes., Nat. Neurosci. 17 (2014) 407-15. doi:10.1038/nn.3647.

[30] Y. Dagon, Y. Avraham, G. Link, O. Zolotarev, R. Mechoulam, E.M. Berry, The synthetic cannabinoid HU-210 attenuates neural damage in diabetic mice and hyperglycemic pheochromocytoma PC12 cells, Neurobiol. Dis. 27 (2007) 174181. doi:10.1016/j.nbd.2007.04.017.

[31] E. Martín-García, L. Bourgoin, A. Cathala, F. Kasanetz, M. Mondesir, A. Gutiérrez-Rodriguez, L. Reguero, J.-F. Fiancette, P. Grandes, U. Spampinato, R. Maldonado, P.V. Piazza, G. Marsicano, V. Deroche-Gamonet, Differential Control of Cocaine Self-Administration by GABAergic and Glutamatergic CB1 
Cannabinoid Receptors., Neuropsychopharmacology. 41 (2016) 2192-205. doi:10.1038/npp.2015.351.

[32] I. Bonilla-Del Río, N. Puente, S. Peñasco, I. Rico, A. Gutiérrez-Rodríguez, I. Elezgarai, A. Ramos, L. Reguero, I. Gerrikagoitia, B.R. Christie, P. Nahirney, P. Grandes, Adolescent ethanol intake alters cannabinoid type-1 receptor localization in astrocytes of the adult mouse hippocampus., Addict. Biol. (2017). doi:10.1111/adb.12585.

[33] A. Gutiérrez-Rodríguez, I. Bonilla-Del Río, N. Puente, S.M. Gómez-Urquijo, C.J. Fontaine, J. Egaña-Huguet, I. Elezgarai, S. Ruehle, B. Lutz, L.M. Robin, E. Soria-Gómez, L. Bellocchio, J.D. Padwal, M. van der Stelt, J. MendizabalZubiaga, L. Reguero, A. Ramos, I. Gerrikagoitia, G. Marsicano, P. Grandes, Localization of the cannabinoid type-1 receptor in subcellular astrocyte compartments of mutant mouse hippocampus., Glia. 66 (2018) 1417-1431. doi:10.1002/glia.23314.

[34] A.C. Howlett, M. Bidaut-Russell, W.A. Devane, L.S. Melvin, M.R. Johnson, M. Herkenham, The cannabinoid receptor: biochemical, anatomical and behavioral characterization., Trends Neurosci. 13 (1990) 420-3.

[35] S.S.-J. Hu, K. Mackie, Distribution of the Endocannabinoid System in the Central Nervous System., Handb. Exp. Pharmacol. 231 (2015) 59-93. doi:10.1007/978-3-319-20825-1_3.

[36] E. Martín-García, L. Bourgoin, A. Cathala, F. Kasanetz, M. Mondesir, A. Gutiérrez-Rodriguez, L. Reguero, J.-F. Fiancette, P. Grandes, U. Spampinato, R. Maldonado, P.V. Piazza, G. Marsicano, V. Deroche-Gamonet, Differential Control of Cocaine Self-Administration by GABAergic and Glutamatergic CB1 Cannabinoid Receptors., Neuropsychopharmacology. 41 (2016) 2192-205. doi:10.1038/npp.2015.351.

[37] K. Monory, H. Blaudzun, F. Massa, N. Kaiser, T. Lemberger, G. Schütz, C.T. Wotjak, B. Lutz, G. Marsicano, Genetic dissection of behavioural and autonomic effects of Delta(9)-tetrahydrocannabinol in mice., PLoS Biol. 5 (2007) e269. doi:10.1371/journal.pbio.0050269.

[38] S. Ruehle, F. Remmers, H. Romo-Parra, F. Massa, M. Wickert, S. Wortge, M. Haring, N. Kaiser, G. Marsicano, H.-C. Pape, B. Lutz, Cannabinoid CB1 Receptor in Dorsal Telencephalic Glutamatergic Neurons: Distinctive Sufficiency for Hippocampus-Dependent and Amygdala-Dependent Synaptic and Behavioral Functions, J. Neurosci. 33 (2013) 10264-10277. doi:10.1523/JNEUROSCI.4171-12.2013.

[39] Y. Kawamura, M. Fukaya, T. Maejima, T. Yoshida, E. Miura, M. Watanabe, T. Ohno-Shosaku, M. Kano, The CB1 cannabinoid receptor is the major cannabinoid receptor at excitatory presynaptic sites in the hippocampus and cerebellum., J. Neurosci. 26 (2006) 2991-3001. doi:10.1523/JNEUROSCI.487205.2006.

[40] A. Ludányi, L. Eross, S. Czirják, J. Vajda, P. Halász, M. Watanabe, M. Palkovits, Z. Maglóczky, T.F. Freund, I. Katona, Downregulation of the CB1 cannabinoid receptor and related molecular elements of the endocannabinoid system in epileptic human hippocampus., J. Neurosci. 28 (2008) 2976-90. doi:10.1523/JNEUROSCI.4465-07.2008.

[41] A. Gutiérrez-Rodríguez, N. Puente, I. Elezgarai, S. Ruehle, B. Lutz, L. Reguero, I. Gerrikagoitia, G. Marsicano, P. Grandes, Anatomical characterization of the cannabinoid CB1 receptor in cell-type-specific mutant mouse rescue models., J. Comp. Neurol. 525 (2017) 302-318. doi:10.1002/cne.24066. 
[42] F. Steindel, R. Lerner, M. Häring, S. Ruehle, G. Marsicano, B. Lutz, K. Monory, Neuron-type specific cannabinoid-mediated G protein signalling in mouse hippocampus., J. Neurochem. 124 (2013) 795-807. doi:10.1111/jnc.12137.

[43] G. Marsicano, S. Goodenough, K. Monory, H. Hermann, M. Eder, A. Cannich, S.C. Azad, M.G. Cascio, S.O. Gutiérrez, M. van der Stelt, M.L. LópezRodriguez, E. Casanova, G. Schütz, W. Zieglgänsberger, V. Di Marzo, C. Behl, B. Lutz, CB1 cannabinoid receptors and on-demand defense against excitotoxicity., Science. 302 (2003) 84-8. doi:10.1126/science.1088208.

[44] I. Katona, Molecular Composition of the Endocannabinoid System at Glutamatergic Synapses, J. Neurosci. 26 (2006) 5628-5637. doi:10.1523/JNEUROSCI.0309-06.2006.

[45] J.J. Rodriguez, K. Mackie, V.M. Pickel, Ultrastructural localization of the CB1 cannabinoid receptor in mu-opioid receptor patches of the rat Caudate putamen nucleus., J. Neurosci. 21 (2001) 823-33.

[46] N. Stella, Cannabinoid and cannabinoid-like receptors in microglia, astrocytes, and astrocytomas., Glia. 58 (2010) 1017-30. doi:10.1002/glia.20983.

[47] J. Han, P. Kesner, M. Metna-Laurent, T. Duan, L. Xu, F. Georges, M. Koehl, D.N. Abrous, J. Mendizabal-Zubiaga, P. Grandes, Q. Liu, G. Bai, W. Wang, L. Xiong, W. Ren, G. Marsicano, X. Zhang, Acute cannabinoids impair working memory through astroglial CB1 receptor modulation of hippocampal LTD., Cell. 148 (2012) 1039-50. doi:10.1016/j.cell.2012.01.037.

[48] B. Bosier, L. Bellocchio, M. Metna-Laurent, E. Soria-Gomez, I. Matias, E. Hebert-Chatelain, A. Cannich, M. Maitre, T. Leste-Lasserre, P. Cardinal, J. Mendizabal-Zubiaga, M.J. Canduela, L. Reguero, E. Hermans, P. Grandes, D. Cota, G. Marsicano, Astroglial CB1 cannabinoid receptors regulate leptin signaling in mouse brain astrocytes, Mol. Metab. 2 (2013) 393-404. doi:10.1016/j.molmet.2013.08.001.

[49] M. Metna-Laurent, G. Marsicano, Rising stars: modulation of brain functions by astroglial type-1 cannabinoid receptors., Glia. 63 (2015) 353-64. doi:10.1002/glia.22773.

[50] G. Bénard, F. Massa, N. Puente, J. Lourenço, L. Bellocchio, E. Soria-Gómez, I. Matias, A. Delamarre, M. Metna-Laurent, A. Cannich, E. Hebert-Chatelain, C.

Mulle, S. Ortega-Gutiérrez, M. Martín-Fontecha, M. Klugmann, S. Guggenhuber, B. Lutz, J. Gertsch, F. Chaouloff, M.L. López-Rodríguez, P. Grandes, R.

Rossignol, G. Marsicano, Mitochondrial CB1 receptors regulate neuronal energy metabolism, Nat. Neurosci. 15 (2012) 558-564. doi:10.1038/nn.3053.

[51] E. Hebert-Chatelain, L. Reguero, N. Puente, B. Lutz, F. Chaouloff, R. Rossignol, P.-V. Piazza, G. Benard, P. Grandes, G. Marsicano, Cannabinoid control of brain bioenergetics: Exploring the subcellular localization of the CB1 receptor., Mol. Metab. 3 (2014) 495-504. doi:10.1016/j.molmet.2014.03.007.

[52] E. Hebert-Chatelain, L. Reguero, N. Puente, B. Lutz, F. Chaouloff, R. Rossignol, P.-V. Piazza, G. Benard, P. Grandes, G. Marsicano, Studying mitochondrial CB1 receptors: Yes we can., Mol. Metab. 3 (2014) 339. doi:10.1016/j.molmet.2014.03.008.

[53] E. Hebert-Chatelain, T. Desprez, R. Serrat, L. Bellocchio, E. Soria-Gomez, A. Busquets-Garcia, A.C. Pagano Zottola, A. Delamarre, A. Cannich, P. Vincent, M. Varilh, L.M. Robin, G. Terral, M.D. García-Fernández, M. Colavita, W. Mazier, F. Drago, N. Puente, L. Reguero, I. Elezgarai, J.-W. Dupuy, D. Cota, M.-L. Lopez-Rodriguez, G. Barreda-Gómez, F. Massa, P. Grandes, G. Bénard, G. Marsicano, A cannabinoid link between mitochondria and memory., Nature. 539 
(2016) 555-559. doi:10.1038/nature20127.

[54] M. Koch, L. Varela, J.G. Kim, J.D. Kim, F. Hernández-Nuño, S.E. Simonds, C.M. Castorena, C.R. Vianna, J.K. Elmquist, Y.M. Morozov, P. Rakic, I. Bechmann, M.A. Cowley, K. Szigeti-Buck, M.O. Dietrich, X.-B. Gao, S. Diano, T.L. Horvath, Hypothalamic POMC neurons promote cannabinoid-induced feeding., Nature. 519 (2015) 45-50. doi:10.1038/nature14260.

[55] S. Munro, K.L. Thomas, M. Abu-Shaar, Molecular characterization of a peripheral receptor for cannabinoids., Nature. 365 (1993) 61-5. doi:10.1038/365061a0.

[56] S. Galiègue, S. Mary, J. Marchand, D. Dussossoy, D. Carrière, P. Carayon, M. Bouaboula, D. Shire, G. Le Fur, P. Casellas, Expression of central and peripheral cannabinoid receptors in human immune tissues and leukocyte subpopulations., Eur. J. Biochem. 232 (1995) 54-61.

[57] C. Benito, E. Nunez, R.M. Tolon, E.J. Carrier, A. Rabano, C.J. Hillard, J. Romero, Cannabinoid CB2 receptors and fatty acid amide hydrolase are selectively overexpressed in neuritic plaque-associated glia in Alzheimer's disease brains, J Neurosci. 23 (2003) 11136-11141.

http://www.ncbi.nlm.nih.gov/entrez/query.fcgi?cmd=Retrieve\&db=PubMed\&do $\mathrm{pt}=$ Citation\&list_uids=14657172.

[58] Y. Yiangou, P. Facer, P. Durrenberger, I.P. Chessell, A. Naylor, C. Bountra, R.R. Banati, P. Anand, COX-2, CB2 and P2X7-immunoreactivities are increased in activated microglial cells/macrophages of multiple sclerosis and amyotrophic lateral sclerosis spinal cord, BMC Neurol. 6 (2006) 12. doi:1471-2377-6-12 [pii]10.1186/1471-2377-6-12.

[59] M. Guzman, C. Sanchez, I. Galve-Roperh, Control of the cell survival/death decision by cannabinoids, J Mol Med. 78 (2001) 613-625.

http://www.ncbi.nlm.nih.gov/entrez/query.fcgi?cmd=Retrieve\&db=PubMed\&do $\mathrm{pt}=$ Citation\&list_uids $=11269508$.

[60] M.D. Van Sickle, M. Duncan, P.J. Kingsley, A. Mouihate, P. Urbani, K. Mackie, N. Stella, A. Makriyannis, D. Piomelli, J.S. Davison, L.J. Marnett, V. Di Marzo, Q.J. Pittman, K.D. Patel, K.A. Sharkey, Identification and functional characterization of brainstem cannabinoid CB2 receptors., Science. 310 (2005) 329-32. doi:10.1126/science.1115740.

[61] E.S. Onaivi, H. Ishiguro, J.-P. Gong, S. Patel, A. Perchuk, P.A. Meozzi, L. Myers, Z. Mora, P. Tagliaferro, E. Gardner, A. Brusco, B.E. Akinshola, Q.-R. Liu, B. Hope, S. Iwasaki, T. Arinami, L. Teasenfitz, G.R. Uhl, Discovery of the presence and functional expression of cannabinoid CB2 receptors in brain., Ann. N. Y. Acad. Sci. 1074 (2006) 514-36. doi:10.1196/annals.1369.052.

[62] M.S. Garcia-Gutierrez, J.M. Perez-Ortiz, A. Gutierrez-Adan, J. Manzanares, Depression-resistant endophenotype in mice overexpressing cannabinoid $\mathrm{CB}(2)$ receptors, Br J Pharmacol. 160 (2010) 1773-1784.

http://www.ncbi.nlm.nih.gov/entrez/query.fcgi?cmd=Retrieve\&db=PubMed\&do $\mathrm{pt}=$ Citation\&list_uids=20649579.

[63] J.-P. Gong, E.S. Onaivi, H. Ishiguro, Q.-R. Liu, P.A. Tagliaferro, A. Brusco, G.R. Uhl, Cannabinoid CB2 receptors: immunohistochemical localization in rat brain., Brain Res. 1071 (2006) 10-23. doi:10.1016/j.brainres.2005.11.035.

[64] H.-Y. Zhang, M. Gao, Q.-R. Liu, G.-H. Bi, X. Li, H.-J. Yang, E.L. Gardner, J. Wu, Z.-X. Xi, Cannabinoid CB2 receptors modulate midbrain dopamine neuronal activity and dopamine-related behavior in mice., Proc. Natl. Acad. Sci. U. S. A. 111 (2014) E5007-15. doi:10.1073/pnas.1413210111. 
[65] G.A. Cabral, E.S. Raborn, L. Griffin, J. Dennis, F. Marciano-Cabral, CB2 receptors in the brain: role in central immune function, Br J Pharmacol. 153 (2008) 240-251. doi:10.1038/sj.bjp.0707584.

[66] B.K. Atwood, K. Mackie, CB2: a cannabinoid receptor with an identity crisis., Br. J. Pharmacol. 160 (2010) 467-79. doi:10.1111/j.1476-5381.2010.00729.x.

[67] S.J. Carlisle, F. Marciano-Cabral, A. Staab, C. Ludwick, G.A. Cabral, Differential expression of the CB2 cannabinoid receptor by rodent macrophages and macrophage-like cells in relation to cell activation., Int. Immunopharmacol. 2 (2002) 69-82.

[68] J.M. Derocq, M. Ségui, J. Marchand, G. Le Fur, P. Casellas, Cannabinoids enhance human B-cell growth at low nanomolar concentrations., FEBS Lett. 369 (1995) 177-82.

[69] G. Griffin, E.J. Wray, Q. Tao, S.D. McAllister, W.K. Rorrer, M.M. Aung, B.R. Martin, M.E. Abood, Evaluation of the cannabinoid CB2 receptor-selective antagonist, SR144528: further evidence for cannabinoid CB2 receptor absence in the rat central nervous system., Eur. J. Pharmacol. 377 (1999) 117-25.

[70] T. Sugiura, S. Kondo, S. Kishimoto, T. Miyashita, S. Nakane, T. Kodaka, Y. Suhara, H. Takayama, K. Waku, Evidence that 2-arachidonoylglycerol but not Npalmitoylethanolamine or anandamide is the physiological ligand for the cannabinoid CB2 receptor. Comparison of the agonistic activities of various cannabinoid receptor ligands in HL-60 cells., J. Biol. Chem. 275 (2000) 605-12.

[71] A. López, N. Aparicio, M.R. Pazos, M.T. Grande, M.A. Barreda-Manso, I. Benito-Cuesta, C. Vázquez, M. Amores, G. Ruiz-Pérez, E. García-García, M. Beatka, R.M. Tolón, B.N. Dittel, C.J. Hillard, J. Romero, Cannabinoid CB2 receptors in the mouse brain: relevance for Alzheimer's disease., J. Neuroinflammation. 15 (2018) 158. doi:10.1186/s12974-018-1174-9.

[72] J.C. Ashton, D. Friberg, C.L. Darlington, P.F. Smith, Expression of the cannabinoid CB2 receptor in the rat cerebellum: an immunohistochemical study., Neurosci. Lett. 396 (2006) 113-6. doi:10.1016/j.neulet.2005.11.038.

[73] J.-H. Baek, Y. Zheng, C.L. Darlington, P.F. Smith, Cannabinoid CB2 receptor expression in the rat brainstem cochlear and vestibular nuclei., Acta Otolaryngol. 128 (2008) 961-7. doi:10.1080/00016480701796944.

[74] E.S. Onaivi, H. Ishiguro, J.-P. Gong, S. Patel, P.A. Meozzi, L. Myers, A. Perchuk, Z. Mora, P.A. Tagliaferro, E. Gardner, A. Brusco, B.E. Akinshola, Q.R. Liu, S.S. Chirwa, B. Hope, J. Lujilde, T. Inada, S. Iwasaki, D. Macharia, L. Teasenfitz, T. Arinami, G.R. Uhl, Functional expression of brain neuronal CB2 cannabinoid receptors are involved in the effects of drugs of abuse and in depression., Ann. N. Y. Acad. Sci. 1139 (2008) 434-49. doi:10.1196/annals.1432.036.

[75] J.L. Lanciego, P. Barroso-Chinea, A.J. Rico, L. Conte-Perales, L. Callén, E. Roda, V. Gómez-Bautista, I.P. López, C. Lluis, J.L. Labandeira-García, R. Franco, Expression of the mRNA coding the cannabinoid receptor 2 in the pallidal complex of Macaca fascicularis., J. Psychopharmacol. 25 (2011) 97-104. doi:10.1177/0269881110367732.

[76] E.S. Onaivi, Neuropsychobiological evidence for the functional presence and expression of cannabinoid CB2 receptors in the brain., Neuropsychobiology. 54 (2006) 231-46. doi:10.1159/000100778.

[77] E.S. Onaivi, H. Ishiguro, J.-P. Gong, S. Patel, P.A. Meozzi, L. Myers, A. Perchuk, Z. Mora, P.A. Tagliaferro, E. Gardner, A. Brusco, B.E. Akinshola, B. Hope, J. Lujilde, T. Inada, S. Iwasaki, D. Macharia, L. Teasenfitz, T. Arinami, 
G.R. Uhl, Brain neuronal CB2 cannabinoid receptors in drug abuse and depression: from mice to human subjects., PLoS One. 3 (2008) e1640. doi:10.1371/journal.pone.0001640.

[78] A. Brusco, P. Tagliaferro, T. Saez, E.S. Onaivi, Postsynaptic localization of CB2 cannabinoid receptors in the rat hippocampus., Synapse. 62 (2008) 944-9. doi:10.1002/syn.20569.

[79] S. Sierra, N. Luquin, A.J. Rico, V. Gómez-Bautista, E. Roda, I.G. Dopeso-Reyes, A. Vázquez, E. Martínez-Pinilla, J.L. Labandeira-García, R. Franco, J.L. Lanciego, Detection of cannabinoid receptors CB1 and CB2 within basal ganglia output neurons in macaques: changes following experimental parkinsonism., Brain Struct. Funct. 220 (2015) 2721-38. doi:10.1007/s00429-014-0823-8.

[80] Q.-R. Liu, C.-H. Pan, A. Hishimoto, C.-Y. Li, Z.-X. Xi, A. Llorente-Berzal, M.P. Viveros, H. Ishiguro, T. Arinami, E.S. Onaivi, G.R. Uhl, Species differences in cannabinoid receptor 2 (CNR2 gene): identification of novel human and rodent CB2 isoforms, differential tissue expression and regulation by cannabinoid receptor ligands., Genes. Brain. Behav. 8 (2009) 519-30. doi:10.1111/j.1601183X.2009.00498.x.

[81] S. Zou, U. Kumar, Cannabinoid Receptors and the Endocannabinoid System: Signaling and Function in the Central Nervous System., Int. J. Mol. Sci. 19 (2018) 833. doi:10.3390/ijms19030833.

[82] H.-C. Lu, K. Mackie, An Introduction to the Endogenous Cannabinoid System., Biol. Psychiatry. 79 (2016) 516-25. doi:10.1016/j.biopsych.2015.07.028.

[83] R.G. Pertwee, A.C. Howlett, M.E. Abood, S.P.H. Alexander, V. Di Marzo, M.R. Elphick, P.J. Greasley, H.S. Hansen, G. Kunos, K. Mackie, R. Mechoulam, R.A. Ross, International Union of Basic and Clinical Pharmacology. LXXIX. Cannabinoid receptors and their ligands: beyond $\mathrm{CB}_{1}$ and $\mathrm{CB}_{2}$., Pharmacol. Rev. 62 (2010) 588-631. doi:10.1124/pr.110.003004.

[84] M. Kano, T. Ohno-Shosaku, Y. Hashimotodani, M. Uchigashima, M. Watanabe, Endocannabinoid-mediated control of synaptic transmission., Physiol. Rev. 89 (2009) 309-80. doi:10.1152/physrev.00019.2008.

[85] W.A. Devane, L. Hanus, A. Breuer, R.G. Pertwee, L.A. Stevenson, G. Griffin, D. Gibson, A. Mandelbaum, A. Etinger, R. Mechoulam, Isolation and structure of a brain constituent that binds to the cannabinoid receptor., Science. 258 (1992) 1946-9.

[86] R. Mechoulam, S. Ben-Shabat, L. Hanus, M. Ligumsky, N.E. Kaminski, A.R. Schatz, A. Gopher, S. Almog, B.R. Martin, D.R. Compton, Identification of an endogenous 2-monoglyceride, present in canine gut, that binds to cannabinoid receptors., Biochem. Pharmacol. 50 (1995) 83-90.

[87] H. Cadas, S. Gaillet, M. Beltramo, L. Venance, D. Piomelli, Biosynthesis of an endogenous cannabinoid precursor in neurons and its control by calcium and cAMP., J. Neurosci. 16 (1996) 3934-42.

[88] F. Fezza, M. Bari, R. Florio, E. Talamonti, M. Feole, M. Maccarrone, Endocannabinoids, related compounds and their metabolic routes., Molecules. 19 (2014) 17078-106. doi:10.3390/molecules191117078.

[89] Y. Okamoto, J. Morishita, K. Tsuboi, T. Tonai, N. Ueda, Molecular characterization of a phospholipase D generating anandamide and its congeners., J. Biol. Chem. 279 (2004) 5298-305. doi:10.1074/jbc.M306642200.

[90] V. Di Marzo, N. Stella, A. Zimmer, Endocannabinoid signalling and the deteriorating brain, Nat. Rev. Neurosci. 16 (2015) 30-42. doi:10.1038/nrn3876.

[91] T.P. Dinh, D. Carpenter, F.M. Leslie, T.F. Freund, I. Katona, S.L. Sensi, S. 
Kathuria, D. Piomelli, Brain monoglyceride lipase participating in endocannabinoid inactivation., Proc. Natl. Acad. Sci. U. S. A. 99 (2002) 1081924. doi:10.1073/pnas.152334899.

[92] N. Ueda, Endocannabinoid hydrolases., Prostaglandins Other Lipid Mediat. 6869 (2002) 521-34.

[93] M. Egertová, B.F. Cravatt, M.R. Elphick, Comparative analysis of fatty acid amide hydrolase and $\operatorname{cb}(1)$ cannabinoid receptor expression in the mouse brain: evidence of a widespread role for fatty acid amide hydrolase in regulation of endocannabinoid signaling., Neuroscience. 119 (2003) 481-96.

[94] Y. Gao, D. V Vasilyev, M.B. Goncalves, F. V Howell, C. Hobbs, M. Reisenberg, R. Shen, M.-Y. Zhang, B.W. Strassle, P. Lu, L. Mark, M.J. Piesla, K. Deng, E. V Kouranova, R.H. Ring, G.T. Whiteside, B. Bates, F.S. Walsh, G. Williams, M.N. Pangalos, T.A. Samad, P. Doherty, Loss of retrograde endocannabinoid signaling and reduced adult neurogenesis in diacylglycerol lipase knock-out mice., J. Neurosci. 30 (2010) 2017-24. doi:10.1523/JNEUROSCI.5693-09.2010.

[95] A. Tanimura, M. Yamazaki, Y. Hashimotodani, M. Uchigashima, S. Kawata, M. Abe, Y. Kita, K. Hashimoto, T. Shimizu, M. Watanabe, K. Sakimura, M. Kano, The endocannabinoid 2-arachidonoylglycerol produced by diacylglycerol lipase alpha mediates retrograde suppression of synaptic transmission., Neuron. 65 (2010) 320-7. doi:10.1016/j.neuron.2010.01.021.

[96] M. Herkenham, A.B. Lynn, M.D. Little, M.R. Johnson, L.S. Melvin, B.R. de Costa, K.C. Rice, Cannabinoid receptor localization in brain., Proc. Natl. Acad. Sci. U. S. A. 87 (1990) 1932-6.

[97] B. Szabo, S. Siemes, I. Wallmichrath, Inhibition of GABAergic neurotransmission in the ventral tegmental area by cannabinoids., Eur. J. Neurosci. 15 (2002) 2057-61.

[98] F. Mátyás, G.M. Urbán, M. Watanabe, K. Mackie, A. Zimmer, T.F. Freund, I. Katona, Identification of the sites of 2-arachidonoylglycerol synthesis and action imply retrograde endocannabinoid signaling at both GABAergic and glutamatergic synapses in the ventral tegmental area., Neuropharmacology. 54 (2008) 95-107. doi:10.1016/j.neuropharm.2007.05.028.

[99] S. Dubreucq, A. Durand, I. Matias, G. Bénard, E. Richard, E. Soria-Gomez, C. Glangetas, L. Groc, A. Wadleigh, F. Massa, D. Bartsch, G. Marsicano, F. Georges, F. Chaouloff, Ventral tegmental area cannabinoid type-1 receptors control voluntary exercise performance., Biol. Psychiatry. 73 (2013) 895-903. doi:10.1016/j.biopsych.2012.10.025.

[100] C. Kortleven, C. Fasano, D. Thibault, J.-C. Lacaille, L.-E. Trudeau, The endocannabinoid 2-arachidonoylglycerol inhibits long-term potentiation of glutamatergic synapses onto ventral tegmental area dopamine neurons in mice., Eur. J. Neurosci. 33 (2011) 1751-60. doi:10.1111/j.1460-9568.2011.07648.x.

[101] T. Wenger, G. Moldrich, S. Furst, Neuromorphological background of cannabis addiction., Brain Res. Bull. 61 (2003) 125-8.

[102] H. Hermann, G. Marsicano, B. Lutz, Coexpression of the cannabinoid receptor type 1 with dopamine and serotonin receptors in distinct neuronal subpopulations of the adult mouse forebrain., Neuroscience. 109 (2002) 451-60.

[103] M. Pistis, L. Ferraro, L. Pira, G. Flore, S. Tanganelli, G.L. Gessa, P. Devoto, Delta(9)-tetrahydrocannabinol decreases extracellular GABA and increases extracellular glutamate and dopamine levels in the rat prefrontal cortex: an in vivo microdialysis study., Brain Res. 948 (2002) 155-8.

[104] E.D. French, K. Dillon, X. Wu, Cannabinoids excite dopamine neurons in the 
ventral tegmentum and substantia nigra., Neuroreport. 8 (1997) 649-52.

[105] E.D. French, delta9-Tetrahydrocannabinol excites rat VTA dopamine neurons through activation of cannabinoid CB1 but not opioid receptors., Neurosci. Lett. 226 (1997) 159-62.

[106] S.R. Laviolette, A.A. Grace, Cannabinoids Potentiate Emotional Learning Plasticity in Neurons of the Medial Prefrontal Cortex through Basolateral Amygdala Inputs., J. Neurosci. 26 (2006) 6458-68. doi:10.1523/JNEUROSCI.0707-06.2006.

[107] R. Maldonado, O. Valverde, F. Berrendero, Involvement of the endocannabinoid system in drug addiction., Trends Neurosci. 29 (2006) 225-32. doi:10.1016/j.tins.2006.01.008.

[108] K. Mackie, Distribution of cannabinoid receptors in the central and peripheral nervous system., Handb. Exp. Pharmacol. (2005) 299-325.

[109] S.M. Eggan, D.A. Lewis, Immunocytochemical distribution of the cannabinoid CB1 receptor in the primate neocortex: a regional and laminar analysis., Cereb. Cortex. 17 (2007) 175-91. doi:10.1093/cercor/bhj136.

[110] M. Diana, M. Melis, G.L. Gessa, Increase in meso-prefrontal dopaminergic activity after stimulation of CB1 receptors by cannabinoids., Eur. J. Neurosci. 10 (1998) 2825-30.

[111] H.-C. Lin, S.-C. Mao, C.-L. Su, P.-W. Gean, The Role of Prefrontal Cortex CB1 Receptors in the Modulation of Fear Memory, Cereb. Cortex. 19 (2009) 165-175. doi:10.1093/cercor/bhn075.

[112] G. Marsicano, B. Lutz, Expression of the cannabinoid receptor CB1 in distinct neuronal subpopulations in the adult mouse forebrain., Eur. J. Neurosci. 11 (1999) 4213-25.

[113] K. Tsou, K. Mackie, M.C. Sañudo-Peña, J.M. Walker, Cannabinoid CB1 receptors are localized primarily on cholecystokinin-containing GABAergic interneurons in the rat hippocampal formation., Neuroscience. 93 (1999) 969-75.

[114] A.L. Bodor, Endocannabinoid Signaling in Rat Somatosensory Cortex: Laminar Differences and Involvement of Specific Interneuron Types, J. Neurosci. 25 (2005) 6845-6856. doi:10.1523/JNEUROSCI.0442-05.2005.

[115] E.L. Hill, T. Gallopin, I. Férézou, B. Cauli, J. Rossier, P. Schweitzer, B. Lambolez, Functional CB1 receptors are broadly expressed in neocortical GABAergic and glutamatergic neurons., J. Neurophysiol. 97 (2007) 2580-9. doi:10.1152/jn.00603.2006.

[116] M. Egertová, M.R. Elphick, Localisation of cannabinoid receptors in the rat brain using antibodies to the intracellular C-terminal tail of CB., J. Comp. Neurol. 422 (2000) 159-71.

[117] M. Lafourcade, I. Elezgarai, S. Mato, Y. Bakiri, P. Grandes, O.J. Manzoni, Molecular components and functions of the endocannabinoid system in mouse prefrontal cortex., PLoS One. 2 (2007) e709. doi:10.1371/journal.pone.0000709.

[118] D.B. Carr, S.R. Sesack, GABA-containing neurons in the rat ventral tegmental area project to the prefrontal cortex., Synapse. 38 (2000) 114-23. doi:10.1002/1098-2396(200011)38:2<114::AID-SYN2>3.0.CO;2-R.

[119] S. Geisler, C. Derst, R.W. Veh, D.S. Zahm, Glutamatergic Afferents of the Ventral Tegmental Area in the Rat, J. Neurosci. 27 (2007) 5730-5743. doi:10.1523/JNEUROSCI.0012-07.2007.

[120] L. Massi, I. Elezgarai, N. Puente, L. Reguero, P. Grandes, O.J. Manzoni, F. Georges, Cannabinoid receptors in the bed nucleus of the stria terminalis control cortical excitation of midbrain dopamine cells in vivo., J. Neurosci. 28 (2008) 
10496-508. doi:10.1523/JNEUROSCI.2291-08.2008.

[121] M. Egertová, G.M. Simon, B.F. Cravatt, M.R. Elphick, Localization of N-acyl phosphatidylethanolamine phospholipase D (NAPE-PLD) expression in mouse brain: A new perspective on $\mathrm{N}$-acylethanolamines as neural signaling molecules., J. Comp. Neurol. 506 (2008) 604-15. doi:10.1002/cne.21568.

[122] T. Yoshida, M. Fukaya, M. Uchigashima, E. Miura, H. Kamiya, M. Kano, M. Watanabe, Localization of diacylglycerol lipase-alpha around postsynaptic spine suggests close proximity between production site of an endocannabinoid, 2arachidonoyl-glycerol, and presynaptic cannabinoid CB1 receptor., J. Neurosci. 26 (2006) 4740-51. doi:10.1523/JNEUROSCI.0054-06.2006.

[123] W.R. Marrs, J.L. Blankman, E.A. Horne, A. Thomazeau, Y.H. Lin, J. Coy, A.L. Bodor, G.G. Muccioli, S.S.-J. Hu, G. Woodruff, S. Fung, M. Lafourcade, J.P. Alexander, J.Z. Long, W. Li, C. Xu, T. Möller, K. Mackie, O.J. Manzoni, B.F. Cravatt, N. Stella, The serine hydrolase ABHD6 controls the accumulation and efficacy of 2-AG at cannabinoid receptors., Nat. Neurosci. 13 (2010) 951-7. doi:10.1038/nn.2601.

[124] I. Katona, E.A. Rancz, L. Acsady, C. Ledent, K. Mackie, N. Hajos, T.F. Freund, Distribution of CB1 cannabinoid receptors in the amygdala and their role in the control of GABAergic transmission., J. Neurosci. 21 (2001) 9506-18.

[125] M. Pistis, S. Perra, G. Pillolla, M. Melis, G.L. Gessa, A.L. Muntoni, Cannabinoids modulate neuronal firing in the rat basolateral amygdala: evidence for CB1- and non-CB1-mediated actions., Neuropharmacology. 46 (2004) 11525.

[126] J.L. McGaugh, Memory--a century of consolidation., Science. 287 (2000) 24851.

[127] P. Campolongo, B. Roozendaal, V. Trezza, D. Hauer, G. Schelling, J.L. McGaugh, V. Cuomo, Endocannabinoids in the rat basolateral amygdala enhance memory consolidation and enable glucocorticoid modulation of memory., Proc. Natl. Acad. Sci. U. S. A. 106 (2009) 4888-93. doi:10.1073/pnas.0900835106.

[128] R.T. LaLumiere, E.M. Nawar, J.L. McGaugh, Modulation of memory consolidation by the basolateral amygdala or nucleus accumbens shell requires concurrent dopamine receptor activation in both brain regions., Learn. Mem. 12 (2005) 296-301. doi:10.1101/lm.93205.

[129] T. Yoshida, M. Uchigashima, M. Yamasaki, I. Katona, M. Yamazaki, K. Sakimura, M. Kano, M. Yoshioka, M. Watanabe, Unique inhibitory synapse with particularly rich endocannabinoid signaling machinery on pyramidal neurons in basal amygdaloid nucleus., Proc. Natl. Acad. Sci. U. S. A. 108 (2011) 3059-64. doi:10.1073/pnas.1012875108.

[130] G.F. Koob, Drug addiction: the yin and yang of hedonic homeostasis., Neuron. 16 (1996) 893-6.

[131] P.J. Hernandez, K. Sadeghian, A.E. Kelley, Early consolidation of instrumental learning requires protein synthesis in the nucleus accumbens., Nat. Neurosci. 5 (2002) 1327-31. doi:10.1038/nn973.

[132] S. Mato, D. Robbe, N. Puente, P. Grandes, O.J. Manzoni, Presynaptic homeostatic plasticity rescues long-term depression after chronic Delta 9tetrahydrocannabinol exposure., J. Neurosci. 25 (2005) 11619-27. doi:10.1523/JNEUROSCI.2294-05.2005.

[133] J.D. Salamone, M. Correa, A. Farrar, S.M. Mingote, Effort-related functions of nucleus accumbens dopamine and associated forebrain circuits, Psychopharmacology (Berl). 191 (2007) 461-482. doi:10.1007/s00213-006- 
0668-9.

[134] D. Robbe, G. Alonso, F. Duchamp, J. Bockaert, O.J. Manzoni, Localization and mechanisms of action of cannabinoid receptors at the glutamatergic synapses of the mouse nucleus accumbens., J. Neurosci. 21 (2001) 109-16.

[135] M. Uchigashima, M. Narushima, M. Fukaya, I. Katona, M. Kano, M. Watanabe, Subcellular arrangement of molecules for 2-arachidonoyl-glycerol-mediated retrograde signaling and its physiological contribution to synaptic modulation in the striatum., J. Neurosci. 27 (2007) 3663-76. doi:10.1523/JNEUROSCI.044807.2007.

[136] B. Szabo, T. Müller, H. Koch, Effects of cannabinoids on dopamine release in the corpus striatum and the nucleus accumbens in vitro., J. Neurochem. 73 (1999) 1084-9.

[137] J.J. Day, M.F. Roitman, R.M. Wightman, R.M. Carelli, Associative learning mediates dynamic shifts in dopamine signaling in the nucleus accumbens., Nat. Neurosci. 10 (2007) 1020-8. doi:10.1038/nn1923.

[138] H. Malinen, P. Hyytiä, Ethanol self-administration is regulated by CB1 receptors in the nucleus accumbens and ventral tegmental area in alcohol-preferring AA rats., Alcohol. Clin. Exp. Res. 32 (2008) 1976-83. doi:10.1111/j.15300277.2008.00786.x.

[139] B. Sperlágh, K. Windisch, R.D. Andó, E. Sylvester Vizi, Neurochemical evidence that stimulation of CB1 cannabinoid receptors on GABAergic nerve terminals activates the dopaminergic reward system by increasing dopamine release in the rat nucleus accumbens., Neurochem. Int. 54 (2009) 452-7. doi:10.1016/j.neuint.2009.01.017.

[140] A. Aracil-Fernández, J.M. Trigo, M.S. García-Gutiérrez, A. Ortega-Álvaro, A. Ternianov, D. Navarro, P. Robledo, P. Berbel, R. Maldonado, J. Manzanares, Decreased cocaine motor sensitization and self-administration in mice overexpressing cannabinoid $\mathrm{CB}_{2}$ receptors., Neuropsychopharmacology. 37 (2012) 1749-63. doi:10.1038/npp.2012.22.

[141] H.-Y. Zhang, G.-H. Bi, X. Li, J. Li, H. Qu, S.-J. Zhang, C.-Y. Li, E.S. Onaivi, E.L. Gardner, Z.-X. Xi, Q.-R. Liu, Species differences in cannabinoid receptor 2 and receptor responses to cocaine self-administration in mice and rats., Neuropsychopharmacology. 40 (2015) 1037-51. doi:10.1038/npp.2014.297.

[142] H.-Y. Zhang, M. Gao, H. Shen, G.-H. Bi, H.-J. Yang, Q.-R. Liu, J. Wu, E.L. Gardner, A. Bonci, Z.-X. Xi, Expression of functional cannabinoid CB2 receptor in VTA dopamine neurons in rats., Addict. Biol. 22 (2017) 752-765. doi:10.1111/adb.12367.

[143] A.V. Stempel, A. Stumpf, H.-Y. Zhang, T. Özdoğan, U. Pannasch, A.-K. Theis, D.-M. Otte, A. Wojtalla, I. Rácz, A. Ponomarenko, Z.-X. Xi, A. Zimmer, D. Schmitz, Cannabinoid Type 2 Receptors Mediate a Cell Type-Specific Plasticity in the Hippocampus, Neuron. 90 (2016) 795-809. doi:10.1016/j.neuron.2016.03.034.

[144] Z.-X. Xi, X.-Q. Peng, X. Li, R. Song, H.-Y. Zhang, Q.-R. Liu, H.-J. Yang, G.-H. Bi, J. Li, E.L. Gardner, Brain cannabinoid CB2 receptors modulate cocaine’s actions in mice, Nat. Neurosci. 14 (2011) 1160-1166. doi:10.1038/nn.2874.

[145] M.M. Silveira, J.C. Arnold, S.R. Laviolette, C.J. Hillard, M. Celorrio, M.S. Aymerich, W.K. Adams, Seeing through the smoke: Human and animal studies of cannabis use and endocannabinoid signalling in corticolimbic networks, Neurosci. Biobehav. Rev. 76 (2017) 380-395. doi:10.1016/j.neubiorev.2016.09.007. 
[146] R. Maldonado, O. Valverde, F. Berrendero, Involvement of the endocannabinoid system in drug addiction, Trends Neurosci. 29 (2006) 225-232. doi:10.1016/j.tins.2006.01.008.

[147] L.H. Parsons, Y.L. Hurd, Endocannabinoid signalling in reward and addiction., Nat. Rev. Neurosci. 16 (2015) 579-94. doi:10.1038/nrn4004.

[148] G. Tanda, F.E. Pontieri, G. Di Chiara, Cannabinoid and heroin activation of mesolimbic dopamine transmission by a common mu1 opioid receptor mechanism., Science. 276 (1997) 2048-50.

[149] C. Cohen, G. Perrault, C. Voltz, R. Steinberg, P. Soubrié, SR141716, a central cannabinoid $(\mathrm{CB}(1))$ receptor antagonist, blocks the motivational and dopaminereleasing effects of nicotine in rats., Behav. Pharmacol. 13 (2002) 451-63.

[150] B.L. Hungund, I. Szakall, A. Adam, B.S. Basavarajappa, C. Vadasz, Cannabinoid CB1 receptor knockout mice exhibit markedly reduced voluntary alcohol consumption and lack alcohol-induced dopamine release in the nucleus accumbens., J. Neurochem. 84 (2003) 698-704.

[151] G. Soria, V. Mendizábal, C. Touriño, P. Robledo, C. Ledent, M. Parmentier, R. Maldonado, O. Valverde, Lack of CB1 cannabinoid receptor impairs cocaine self-administration., Neuropsychopharmacology. 30 (2005) 1670-80. doi:10.1038/sj.npp.1300707.

[152] E. Valjent, J.M. Mitchell, M.-J. Besson, J. Caboche, R. Maldonado, Behavioural and biochemical evidence for interactions between $\Delta 9$-tetrahydrocannabinol and nicotine, Br. J. Pharmacol. 135 (2002) 564-578. doi:10.1038/sj.bjp.0704479.

[153] J.E. Gallate, T. Saharov, P.E. Mallet, I.S. McGregor, Increased motivation for beer in rats following administration of a cannabinoid CB1 receptor agonist., Eur. J. Pharmacol. 370 (1999) 233-40. http://www.ncbi.nlm.nih.gov/pubmed/10334497 (accessed July 2, 2018).

[154] G. Colombo, S. Serra, G. Brunetti, R. Gomez, S. Melis, G. Vacca, M.M. Carai, L. Gessa, Stimulation of voluntary ethanol intake by cannabinoid receptor agonists in ethanol-preferring sP rats., Psychopharmacology (Berl). 159 (2002) 181-7. doi:10.1007/s002130100887.

[155] O. V Rice, N. Gordon, A.N. Gifford, Conditioned place preference to morphine in cannabinoid CB1 receptor knockout mice., Brain Res. 945 (2002) 135-8. http://www.ncbi.nlm.nih.gov/pubmed/12113961 (accessed July 2, 2018).

[156] A. Castañé, E. Valjent, C. Ledent, M. Parmentier, R. Maldonado, O. Valverde, Lack of CB1 cannabinoid receptors modifies nicotine behavioural responses, but not nicotine abstinence., Neuropharmacology. 43 (2002) 857-67. http://www.ncbi.nlm.nih.gov/pubmed/12384171 (accessed July 2, 2018).

[157] H. Houchi, D. Babovic, O. Pierrefiche, C. Ledent, M. Daoust, M. Naassila, CB1 Receptor Knockout Mice Display Reduced Ethanol-Induced Conditioned Place Preference and Increased Striatal Dopamine D2 Receptors, Neuropsychopharmacology. 30 (2005) 339-349. doi:10.1038/sj.npp.1300568.

[158] M. Martin, C. Ledent, M. Parmentier, R. Maldonado, O. Valverde, Involvement of CB1 cannabinoid receptors in emotional behaviour., Psychopharmacology (Berl). 159 (2002) 379-87. doi:10.1007/s00213-001-0946-5.

[159] M. Navarro, M.R. Carrera, W. Fratta, O. Valverde, G. Cossu, L. Fattore, J.A. Chowen, R. Gomez, I. del Arco, M.A. Villanua, R. Maldonado, G.F. Koob, F. Rodriguez de Fonseca, Functional interaction between opioid and cannabinoid receptors in drug self-administration., J. Neurosci. 21 (2001) 5344-5350. doi:21/14/5344 [pii].

[160] M. Navarro, M.R.A. Carrera, I. Del Arco, J.M. Trigo, G.F. Koob, F. Rodríguez 
de Fonseca, Cannabinoid receptor antagonist reduces heroin self-administration only in dependent rats., Eur. J. Pharmacol. 501 (2004) 235-7.

doi:10.1016/j.ejphar.2004.08.022.

[161] M. Arnone, J. Maruani, F. Chaperon, M.H. Thiébot, M. Poncelet, P. Soubrié, G. Le Fur, Selective inhibition of sucrose and ethanol intake by SR 141716, an antagonist of central cannabinoid (CB1) receptors., Psychopharmacology (Berl). 132 (1997) 104-6.

[162] R.B. Rothman, M.H. Baumann, Monoamine transporters and psychostimulant drugs., Eur. J. Pharmacol. 479 (2003) 23-40.

[163] S. Caillé, L.H. Parsons, Cannabinoid Modulation of Opiate Reinforcement through the Ventral Striatopallidal Pathway, Neuropsychopharmacology. 31 (2006) 804-813. doi:10.1038/sj.npp.1300848.

[164] C. Touriño, C. Ledent, R. Maldonado, O. Valverde, CB1Cannabinoid Receptor Modulates 3,4-Methylenedioxymethamphetamine Acute Responses and Reinforcement, Biol. Psychiatry. 63 (2008) 1030-1038. doi:10.1016/j.biopsych.2007.09.003.

[165] M. Martin, C. Ledent, M. Parmentier, R. Maldonado, O. Valverde, Cocaine, but not morphine, induces conditioned place preference and sensitization to locomotor responses in CB1 knockout mice., Eur. J. Neurosci. 12 (2000) 40384046. doi:10.1046/j.1460-9568.2000.00287.x.

[166] L.-L. Yu, S.-J. Zhou, X.-Y. Wang, J.-F. Liu, Y.-X. Xue, W. Jiang, L. Lu, Effects of cannabinoid $\mathrm{CB}_{1}$ receptor antagonist rimonabant on acquisition and reinstatement of psychostimulant reward memory in mice., Behav. Brain Res. 217 (2011) 111-6. doi:10.1016/j.bbr.2010.10.008.

[167] S.J. Ward, M. Rosenberg, L.A. Dykstra, E.A. Walker, The CB1 antagonist rimonabant (SR141716) blocks cue-induced reinstatement of cocaine seeking and other context and extinction phenomena predictive of relapse., Drug Alcohol Depend. 105 (2009) 248-55. doi:10.1016/j.drugalcdep.2009.07.002.

[168] D. Braida, S. Iosuè, S. Pegorini, M. Sala, 3,4 Methylenedioxymethamphetamineinduced conditioned place preference (CPP) is mediated by endocannabinoid system., Pharmacol. Res. 51 (2005) 177-82. doi:10.1016/j.phrs.2004.07.009.

[169] G. Cossu, C. Ledent, L. Fattore, A. Imperato, G.A. Böhme, M. Parmentier, W. Fratta, Cannabinoid CB1 receptor knockout mice fail to self-administer morphine but not other drugs of abuse., Behav. Brain Res. 118 (2001) 61-5.

[170] L. Fattore, M.C. Martellotta, G. Cossu, M.S. Mascia, W. Fratta, CB1 cannabinoid receptor agonist WIN 55,212-2 decreases intravenous cocaine self-administration in rats., Behav. Brain Res. 104 (1999) 141-6.

[171] L. V Panlilio, M. Solinas, S.A. Matthews, S.R. Goldberg, Previous exposure to THC alters the reinforcing efficacy and anxiety-related effects of cocaine in rats., Neuropsychopharmacology. 32 (2007) 646-57. doi:10.1038/sj.npp.1301109.

[172] D. Braida, M. Sala, Role of the endocannabinoid system in MDMA intracerebral self-administration in rats., Br. J. Pharmacol. 136 (2002) 1089-92. doi:10.1038/sj.bjp.0704825.

[173] Y. Mateo, K.A. Johnson, D.P. Covey, B.K. Atwood, H.-L. Wang, S. Zhang, I. Gildish, R. Cachope, L. Bellocchio, M. Guzmán, M. Morales, J.F. Cheer, D.M. Lovinger, Endocannabinoid Actions on Cortical Terminals Orchestrate Local Modulation of Dopamine Release in the Nucleus Accumbens, Neuron. 96 (2017) 1112-1126.e5. doi:10.1016/j.neuron.2017.11.012.

[174] H.M.B. Lesscher, E. Hoogveld, J.P.H. Burbach, J.M. van Ree, M.A.F.M. Gerrits, Endogenous cannabinoids are not involved in cocaine reinforcement and 
development of cocaine-induced behavioural sensitization., Eur.

Neuropsychopharmacol. 15 (2005) 31-7. doi:10.1016/j.euroneuro.2004.04.003.

[175] T.J. De Vries, Y. Shaham, J.R. Homberg, H. Crombag, K. Schuurman, J. Dieben, L.J. Vanderschuren, A.N. Schoffelmeer, A cannabinoid mechanism in relapse to cocaine seeking., Nat. Med. 7 (2001) 1151-4. doi:10.1038/nm1001-1151.

[176] C.M. Gremel, J.H. Chancey, B.K. Atwood, G. Luo, R. Neve, C. Ramakrishnan, K. Deisseroth, D.M. Lovinger, R.M. Costa, Endocannabinoid Modulation of Orbitostriatal Circuits Gates Habit Formation., Neuron. 90 (2016) 1312-1324. doi:10.1016/j.neuron.2016.04.043.

[177] C. Nazzaro, B. Greco, M. Cerovic, P. Baxter, T. Rubino, M. Trusel, D. Parolaro, T. Tkatch, F. Benfenati, P. Pedarzani, R. Tonini, SK channel modulation rescues striatal plasticity and control over habit in cannabinoid tolerance., Nat. Neurosci. 15 (2012) 284-93. doi:10.1038/nn.3022.

[178] E.J. Nestler, Is there a common molecular pathway for addiction?, Nat. Neurosci. 8 (2005) 1445-1449. doi:10.1038/nn1578.

[179] R. Maldonado, Study of cannabinoid dependence in animals., Pharmacol. Ther. 95 (2002) 153-64.

[180] C. Ledent, O. Valverde, G. Cossu, F. Petitet, J.F. Aubert, F. Beslot, G.A. Böhme, A. Imperato, T. Pedrazzini, B.P. Roques, G. Vassart, W. Fratta, M. Parmentier, Unresponsiveness to cannabinoids and reduced addictive effects of opiates in CB1 receptor knockout mice., Science. 283 (1999) 401-4.

[181] J. Haller, N. Bakos, M. Szirmay, C. Ledent, T.F. Freund, The effects of genetic and pharmacological blockade of the CB1 cannabinoid receptor on anxiety., Eur. J. Neurosci. 16 (2002) 1395-8.

[182] M. Navarro, E. Hernández, R.M. Muñoz, I. del Arco, M.A. Villanúa, M.R. Carrera, F. Rodríguez de Fonseca, Acute administration of the CB1 cannabinoid receptor antagonist SR 141716A induces anxiety-like responses in the rat., Neuroreport. 8 (1997) 491-6.

[183] R. Maldonado, F. Berrendero, A. Ozaita, P. Robledo, Neurochemical basis of cannabis addiction., Neuroscience. 181 (2011) 1-17. doi:10.1016/j.neuroscience.2011.02.035.

[184] S. Kathuria, S. Gaetani, D. Fegley, F. Valiño, A. Duranti, A. Tontini, M. Mor, G. Tarzia, G. La Rana, A. Calignano, A. Giustino, M. Tattoli, M. Palmery, V. Cuomo, D. Piomelli, Modulation of anxiety through blockade of anandamide hydrolysis., Nat. Med. 9 (2003) 76-81. doi:10.1038/nm803.

[185] L.E. Hollister, Health aspects of cannabis: revisited, Int. J. Neuropsychopharmacol. 1 (1998) S1461145798001060. doi:10.1017/S1461145798001060.

[186] T. Hayase, Y. Yamamoto, K. Yamamoto, Persistent anxiogenic effects of a single or repeated doses of cocaine and methamphetamine: interactions with endogenous cannabinoid receptor ligands., Behav. Pharmacol. 16 (2005) 395404.

[187] T. Hayase, Working memory- and anxiety-related behavioral effects of repeated nicotine as a stressor: the role of cannabinoid receptors., BMC Neurosci. 14 (2013) 20. doi:10.1186/1471-2202-14-20.

[188] M.E. Page, V.C. Oropeza, S.E. Sparks, Y. Qian, A.S. Menko, E.J. Van Bockstaele, Repeated cannabinoid administration increases indices of noradrenergic activity in rats., Pharmacol. Biochem. Behav. 86 (2007) 162-8. doi:10.1016/j.pbb.2006.12.020.

[189] N.D. Volkow, G.-J. Wang, F. Telang, J.S. Fowler, D. Alexoff, J. Logan, M. 
Jayne, C. Wong, D. Tomasi, Decreased dopamine brain reactivity in marijuana abusers is associated with negative emotionality and addiction severity, Proc. Natl. Acad. Sci. 111 (2014) E3149-E3156. doi:10.1073/pnas.1411228111.

[190] I. Rácz, E. Nent, E. Erxlebe, A. Zimmer, CB1 receptors modulate affective behaviour induced by neuropathic pain., Brain Res. Bull. 114 (2015) 42-48. doi:10.1016/j.brainresbull.2015.03.005.

[191] N.D. Volkow, A.J. Hampson, R.D. Baler, Don’t Worry, Be Happy: Endocannabinoids and Cannabis at the Intersection of Stress and Reward., Annu. Rev. Pharmacol. Toxicol. 57 (2017) 285-308. doi:10.1146/annurev-pharmtox010716-104615.

[192] B. Lutz, The endocannabinoid system and extinction learning., Mol. Neurobiol. 36 (2007) 92-101. doi:10.1007/s12035-007-8004-X.

[193] K. Monory, M. Polack, A. Remus, B. Lutz, M. Korte, Cannabinoid CB1 Receptor Calibrates Excitatory Synaptic Balance in the Mouse Hippocampus, J. Neurosci. 35 (2015) 3842-3850. doi:10.1523/JNEUROSCI.3167-14.2015.

[194] J.A. Lopez-Moreno, G. González-Cuevas, F. Rodríguez de Fonseca, M. Navarro, Long-Lasting Increase of Alcohol Relapse by the Cannabinoid Receptor Agonist WIN 55,212-2 during Alcohol Deprivation, J. Neurosci. 24 (2004) 8245-8252. doi:10.1523/JNEUROSCI.2179-04.2004.

[195] L. Fattore, M. Spano, V. Melis, P. Fadda, W. Fratta, Differential effect of opioid and cannabinoid receptor blockade on heroin-seeking reinstatement and cannabinoid substitution in heroin-abstinent rats, Br. J. Pharmacol. 163 (2011) 1550-1562. doi:10.1111/j.1476-5381.2011.01459.x.

[196] T.J. De Vries, J.R. Homberg, R. Binnekade, H. Raasø, A.N.M. Schoffelmeer, Cannabinoid modulation of the reinforcing and motivational properties of heroin and heroin-associated cues in rats, Psychopharmacology (Berl). 168 (2003) 164169. doi:10.1007/s00213-003-1422-1.

[197] L. Alvarez-Jaimes, I. Polis, L.H. Parsons, Attenuation of cue-induced heroinseeking behavior by cannabinoid CB1 antagonist infusions into the nucleus accumbens core and prefrontal cortex, but not basolateral amygdala., Neuropsychopharmacology. 33 (2008) 2483-93. doi:10.1038/sj.npp.1301630.

[198] Z.-X. Xi, J.G. Gilbert, X.-Q. Peng, A.C. Pak, X. Li, E.L. Gardner, Cannabinoid CB1 Receptor Antagonist AM251 Inhibits Cocaine-Primed Relapse in Rats: Role of Glutamate in the Nucleus Accumbens, J. Neurosci. 26 (2006) 8531-8536. doi:10.1523/JNEUROSCI.0726-06.2006.

[199] J.D. Robinson, P.M. Cinciripini, M. Karam-Hage, H.-J. Aubin, L.C. Dale, R. Niaura, R.M. Anthenelli, STRATUS Group, Pooled analysis of three randomized, double-blind, placebo controlled trials with rimonabant for smoking cessation., Addict. Biol. 23 (2018) 291-303. doi:10.1111/adb.12508.

[200] M. Soyka, G. Koller, P. Schmidt, O.-M. Lesch, M. Leweke, C. Fehr, H. Gann, K.F. Mann, ACTOL Study Investigators, Cannabinoid receptor 1 blocker rimonabant (SR 141716) for treatment of alcohol dependence: results from a placebo-controlled, double-blind trial., J. Clin. Psychopharmacol. 28 (2008) 31724. doi:10.1097/JCP.0b013e318172b8bc.

[201] C.S. Wilcox, E.P. Noble, N. Oskooilar, ANKK1/DRD2 locus variants are associated with rimonabant efficacy in aiding smoking cessation: pilot data., $\mathrm{J}$. Investig. Med. 59 (2011) 1280-3. doi:10.2130/JIM.0b013e31823581fa.

[202] G.A. Bray, D.H. Ryan, Drug Treatment of the Overweight Patient, Gastroenterology. 132 (2007) 2239-2252. doi:10.1053/j.gastro.2007.03.053.

[203] D. Taylor, Withdrawal of Rimonabant--walking the tightrope of 21st century 
pharmaceutical regulation?, Curr. Drug Saf. 4 (2009) 2-4.

http://www.ncbi.nlm.nih.gov/pubmed/19256104 (accessed July 2, 2018).

[204] R. Bergholm, K. Sevastianova, A. Santos, A. Kotronen, M. Urjansson, A. Hakkarainen, J. Lundbom, M. Tiikkainen, A. Rissanen, N. Lundbom, H. YkiJärvinen, CB(1) blockade-induced weight loss over 48 weeks decreases liver fat in proportion to weight loss in humans., Int. J. Obes. (Lond). 37 (2013) 699-703. doi:10.1038/ijo.2012.116.

[205] M.K. Sharma, P.R. Murumkar, A.M. Kanhed, R. Giridhar, M.R. Yadav, Prospective therapeutic agents for obesity: Molecular modification approaches of centrally and peripherally acting selective cannabinoid 1 receptor antagonists, Eur. J. Med. Chem. 79 (2014) 298-339. doi:10.1016/j.ejmech.2014.04.011.

[206] M.K. Sharma, P.R. Murumkar, M.A. Barmade, R. Giridhar, M.R. Yadav, A comprehensive patents review on cannabinoid 1 receptor antagonists as antiobesity agents., Expert Opin. Ther. Pat. 25 (2015) 1093-116. doi:10.1517/13543776.2015.1064898.

[207] Z. Pang, N.N. Wu, W. Zhao, D.C. Chain, E. Schaffer, X. Zhang, P. Yamdagni, V.A. Palejwala, C. Fan, S.G. Favara, H.M. Dressler, K.D. Economides, D. Weinstock, J.S. Cavallo, S. Naimi, A.-M. Galzin, E. Guillot, M.-P. Pruniaux, M.J. Tocci, H.G. Polites, The central cannabinoid CB1 receptor is required for diet-induced obesity and rimonabant's antiobesity effects in mice., Obesity (Silver Spring). 19 (2011) 1923-34. doi:10.1038/oby.2011.250.

[208] F.J. Janssen, M. van der Stelt, Inhibitors of diacylglycerol lipases in neurodegenerative and metabolic disorders., Bioorg. Med. Chem. Lett. 26 (2016) 3831-7. doi:10.1016/j.bmcl.2016.06.076.

[209] C. Silvestri, V. Di Marzo, Second generation CB1 receptor blockers and other inhibitors of peripheral endocannabinoid overactivity and the rationale of their use against metabolic disorders., Expert Opin. Investig. Drugs. 21 (2012) 130922. doi:10.1517/13543784.2012.704019.

[210] M. Vallée, S. Vitiello, L. Bellocchio, E. Hébert-Chatelain, S. Monlezun, E. Martin-Garcia, F. Kasanetz, G.L. Baillie, F. Panin, A. Cathala, V. RoullotLacarrière, S. Fabre, D.P. Hurst, D.L. Lynch, D.M. Shore, V. Deroche-Gamonet, U. Spampinato, J.-M. Revest, R. Maldonado, P.H. Reggio, R.A. Ross, G. Marsicano, P.V. Piazza, Pregnenolone can protect the brain from cannabis intoxication., Science. 343 (2014) 94-8. doi:10.1126/science.1243985.

[211] National Institutes of Health. Clinicaltrials.gov. Accessed September 5, 2018. www.clinicaltrials.gov.

[212] B.J. Everitt, T.W. Robbins, Drug Addiction: Updating Actions to Habits to Compulsions Ten Years On, Annu. Rev. Psychol. 67 (2016) 23-50. doi:10.1146/annurev-psych-122414-033457.

[213] K.K. Harris, M. Zopey, T.C. Friedman, Metabolic effects of smoking cessation., Nat. Rev. Endocrinol. 12 (2016) 299-308. doi:10.1038/nrendo.2016.32.

[214] L. Billing, K.D. Ersche, Cocaine's appetite for fat and the consequences on body weight., Am. J. Drug Alcohol Abuse. 41 (2015) 115-8. doi:10.3109/00952990.2014.966196.

[215] R. Abuhasira, L. Shbiro, Y. Landschaft, Medical use of cannabis and cannabinoids containing products - Regulations in Europe and North America, Eur. J. Intern. Med. 49 (2018) 2-6. doi:10.1016/j.ejim.2018.01.001.

[216] A. Aracil-Fernandez, J.M. Trigo, M.S. Garcia-Gutierrez, A. Ortega-Alvaro, A. Ternianov, D. Navarro, P. Robledo, P. Berbel, R. Maldonado, J. Manzanares, Decreased cocaine motor sensitization and self-administration in mice 
overexpressing cannabinoid CB(2) receptors, Neuropsychopharmacology. 37 (2012) 1749-1763. doi:npp201222 [pii]10.1038/npp.2012.22.

[217] A. Ortega-Alvaro, A. Aracil-Fernandez, M.S. Garcia-Gutierrez, F. Navarrete, J. Manzanares, Deletion of CB2 cannabinoid receptor induces schizophrenia-related behaviors in mice, Neuropsychopharmacology. 36 (2011) 1489-1504.

http://www.ncbi.nlm.nih.gov/entrez/query.fcgi?cmd=Retrieve\&db=PubMed\&do $\mathrm{pt}=$ Citation\&list_uids=21430651.

[218] E. Blanco-Calvo, P. Rivera, S. Arrabal, A. Vargas, F.J. Pavon, A. Serrano, E. Castilla-Ortega, P. Galeano, L. Rubio, J. Suarez, F. Rodriguez de Fonseca, Pharmacological blockade of either cannabinoid CB1 or CB2 receptors prevents both cocaine-induced conditioned locomotion and cocaine-induced reduction of cell proliferation in the hippocampus of adult male rat, Front Integr Neurosci. 7 (2014) 106. doi:10.3389/fnint.2013.00106.

[219] P. Adamczyk, J. Miszkiel, A.C. McCreary, M. Filip, M. Papp, E. Przegalinski, The effects of cannabinoid CB1, CB2 and vanilloid TRPV1 receptor antagonists on cocaine addictive behavior in rats, Brain Res. 1444 (2012) 45-54.

http://www.ncbi.nlm.nih.gov/entrez/query.fcgi?cmd=Retrieve\&db=PubMed\&do $\mathrm{pt}=$ Citation\&list_uids=22325096.

[220] R. Garcia-Cabrerizo, M.J. Garcia-Fuster, Opposite regulation of cannabinoid CB1 and CB2 receptors in the prefrontal cortex of rats treated with cocaine during adolescence, Neurosci Lett. 615 (2016) 60-65.

doi:10.1016/j.neulet.2016.01.018.

[221] P. Rivera, M. Miguens, S.M. Coria, L. Rubio, A. Higuera-Matas, F.J. BermudezSilva, F.R. de Fonseca, J. Suarez, E. Ambrosio, Cocaine self-administration differentially modulates the expression of endogenous cannabinoid systemrelated proteins in the hippocampus of Lewis vs. Fischer 344 rats, Int J Neuropsychopharmacol. 16 (2013) 1277-1293. doi:10.1017/S1461145712001186.

[222] A. Ortega-Alvaro, A. Ternianov, A. Aracil-Fernandez, F. Navarrete, M.S. Garcia-Gutierrez, J. Manzanares, Role of cannabinoid CB2 receptor in the reinforcing actions of ethanol, Addict Biol. 20 (2015) 43-55. doi:10.1111/adb.12076.

[223] S. Al Mansouri, S. Ojha, E. Al Maamari, M. Al Ameri, S.M. Nurulain, A. Bahi, The cannabinoid receptor 2 agonist, beta-caryophyllene, reduced voluntary alcohol intake and attenuated ethanol-induced place preference and sensitivity in mice, Pharmacol Biochem Behav. 124 (2014) 260-268. doi:10.1016/j.pbb.2014.06.025.

[224] H. Ishiguro, S. Iwasaki, L. Teasenfitz, S. Higuchi, Y. Horiuchi, T. Saito, T. Arinami, E.S. Onaivi, Involvement of cannabinoid CB2 receptor in alcohol preference in mice and alcoholism in humans, Pharmacogenomics J. 7 (2007) 380-385.

http://www.ncbi.nlm.nih.gov/entrez/query.fcgi?cmd=Retrieve\&db=PubMed\&do $\mathrm{pt}=$ Citation\&list_uids=17189959.

[225] B. Pradier, E. Erxlebe, A. Markert, I. Racz, Interaction of cannabinoid receptor 2 and social environment modulates chronic alcohol consumption, Behav Brain Res. 287 (2015) 163-171. doi:10.1016/j.bbr.2015.03.051.

[226] A. Serrano, P. Rivera, F.J. Pavon, J. Decara, J. Suarez, F. Rodriguez de Fonseca, L.H. Parsons, Differential effects of single versus repeated alcohol withdrawal on the expression of endocannabinoid system-related genes in the rat amygdala, Alcohol Clin Exp Res. 36 (2012) 984-994. doi:10.1111/j.1530- 
0277.2011.01686.x.

[227] L. Sanchez-Marin, F.J. Pavon, J. Decara, J. Suarez, A. Gavito, E. Castilla-Ortega, F. Rodriguez de Fonseca, A. Serrano, Effects of Intermittent Alcohol Exposure on Emotion and Cognition: A Potential Role for the Endogenous Cannabinoid System and Neuroinflammation, Front Behav Neurosci. 11 (2017) 15. doi:10.3389/fnbeh.2017.00015.

[228] F. Navarrete, M. Rodríguez-Arias, E. Martín-García, D. Navarro, M.S. GarcíaGutiérrez, M.A. Aguilar, A. Aracil-Fernández, P. Berbel, J. Miñarro, R. Maldonado, J. Manzanares, Role of CB2 cannabinoid receptors in the rewarding, reinforcing, and physical effects of nicotine., Neuropsychopharmacology. 38 (2013) 2515-24. doi:10.1038/npp.2013.157.

[229] I. Gamaleddin, A. Zvonok, A. Makriyannis, S.R. Goldberg, B. Le Foll, Effects of a selective cannabinoid CB2 agonist and antagonist on intravenous nicotine self administration and reinstatement of nicotine seeking, PLoS One. 7 (2012) e29900. doi:10.1371/journal.pone.0029900PONE-D-11-14313 [pii].

[230] B.M. Ignatowska-Jankowska, P.P. Muldoon, A.H. Lichtman, M.I. Damaj, The cannabinoid CB2 receptor is necessary for nicotine-conditioned place preference, but not other behavioral effects of nicotine in mice, Psychopharmacol. 229 (2013) 591-601. doi:10.1007/s00213-013-3117-6.

[231] V.M. Andre, C. Cepeda, D.M. Cummings, E.L. Jocoy, Y.E. Fisher, X. William Yang, M.S. Levine, Dopamine modulation of excitatory currents in the striatum is dictated by the expression of $\mathrm{D} 1$ or $\mathrm{D} 2$ receptors and modified by endocannabinoids, Eur J Neurosci. 31 (2010) 14-28. doi:10.1111/j.14609568.2009.07047.x.

[232] S.D. Glick, E.M. Sell, S.E. McCallum, I.M. Maisonneuve, Brain regions mediating alpha3beta4 nicotinic antagonist effects of 18-MC on nicotine selfadministration, Eur J Pharmacol. 669 (2011) 71-75. doi:10.1016/j.ejphar.2011.08.001.

[233] L. Liu, R. Zhao-Shea, J.M. McIntosh, P.D. Gardner, A.R. Tapper, Nicotine persistently activates ventral tegmental area dopaminergic neurons via nicotinic acetylcholine receptors containing alpha4 and alpha6 subunits, Mol Pharmacol. 81 (2012) 541-548. doi:10.1124/mol.111.076661.

[234] R.G. Pertwee, Targeting the endocannabinoid system with cannabinoid receptor agonists: pharmacological strategies and therapeutic possibilities, Philos Trans R Soc L. B Biol Sci. 367 (2012) 3353-3363. doi:10.1098/rstb.2011.0381.

[235] M.S. Garcia-Gutierrez, B. Garcia-Bueno, S. Zoppi, J.C. Leza, J. Manzanares, Chronic blockade of cannabinoid CB2 receptors induces anxiolytic-like actions associated with alterations in GABA(A) receptors, Br J Pharmacol. 165 (2012) 951-964. doi:10.1111/j.1476-5381.2011.01625.x.

[236] M.B. Elliott, R.F. Tuma, P.S. Amenta, M.F. Barbe, J.I. Jallo, Acute effects of a selective cannabinoid-2 receptor agonist on neuroinflammation in a model of traumatic brain injury, J Neurotrauma. 28 (2011) 973-981. doi:10.1089/neu.2010.1672.

[237] A. Mastinu, M. Premoli, G. Ferrari-Toninelli, S. Tambaro, G. Maccarinelli, M. Memo, S.A. Bonini, Cannabinoids in health and disease: pharmacological potential in metabolic syndrome and neuroinflammation, Horm Mol Biol Clin Investig. (2018). doi:10.1515/hmbci-2018-0013.

[238] Y. Persidsky, W. Ho, S.H. Ramirez, R. Potula, M.E. Abood, E. Unterwald, R. Tuma, HIV-1 infection and alcohol abuse: neurocognitive impairment, mechanisms of neurodegeneration and therapeutic interventions, Brain Behav 
Immun. 25 Suppl 1 (2011) S61-70. doi:10.1016/j.bbi.2011.03.001.

[239] T. Cassano, S. Calcagnini, L. Pace, F. De Marco, A. Romano, S. Gaetani, Cannabinoid Receptor 2 Signaling in Neurodegenerative Disorders: From Pathogenesis to a Promising Therapeutic Target, Front Neurosci. 11 (2017) 30. doi:10.3389/fnins.2017.00030.

[240] F. Gado, L. Di Cesare Mannelli, E. Lucarini, S. Bertini, E. Cappelli, M. Digiacomo, L.A. Stevenson, M. Macchia, T. Tuccinardi, C. Ghelardini, R.G. Pertwee, C. Manera, Identification of the First Synthetic Allosteric Modulator of the CB2 Receptors and Evidence of Its Efficacy for Neuropathic Pain Relief, J Med Chem. (2018). doi:10.1021/acs.jmedchem.8b00368. 


\section{Figure 1. Distribution of CB1R and CB2R in the CNS.}

The accumulation of CB1R is high in GABAergic synaptic terminals [17,26,35,39-42], low in glutamatergic synaptic terminals $[22,25,28,38,43,44]$, and very low in astrocytes [33,45-49]. CB1R also localizes to mitochondria of neurons [50-54] and astrocytes [33]. Scattered CB1R labeling has been detected in resting microglia (Grandes et al., unpublished).

Figure 2. Functional localization of CB1R and CB2R in the main structures related to drug addictive properties.

In the ventral tegmental area (VTA), CB1R are found in GABAergic neurons and glutamate presynaptic terminals apposed to dendrites of dopaminergic neurons [89]. CB1R may be expressed as well in the VTA DA neurons [90]. Diacylglycerol lipase $\alpha$ (DAGL $\alpha$ ) is expressed postsynaptically, in DA and non-DA neurons of the VTA, in presynaptic terminals in the nucleus accumbens (NAc) and in synapses of the prefrontal cortex (PFC), where it co-localizes with metabotropic glutamate receptor 5 (mGluR5) and apposes to presynaptic terminals containing $\mathrm{CB} 1 \mathrm{R}$, suggesting its activation through 2-arachidonoylglycerol (2-AG) $\quad[24,87,105]$. $\alpha / \beta$-hydrolase domain-containing 6 (ABHD6), the enzyme that metabolizes 2-AG, is found in the spines facing CB1R in the PFC [111]. Excitatory projections from the PFC synapse with GABAergic interneurons and dopaminergic neurons in the VTA $[106,107]$. In the NAc, CB1R are localized in excitatory terminals coming from the PFC and in medium spiny neurons and parvalvumin interneurons, but not in the DA terminals. Inhibition of GABA release controls DA outflow [86,124-127]. CB2R have been described in non-dopaminergic and dopaminergic VTA neurons [128-131], where its stimulation induces neuronal inhibition and reduction of DA release in the NAc, associated with diminished drug intake [129131]. CCK+: Cholecystokinin-positive. 
Nodr
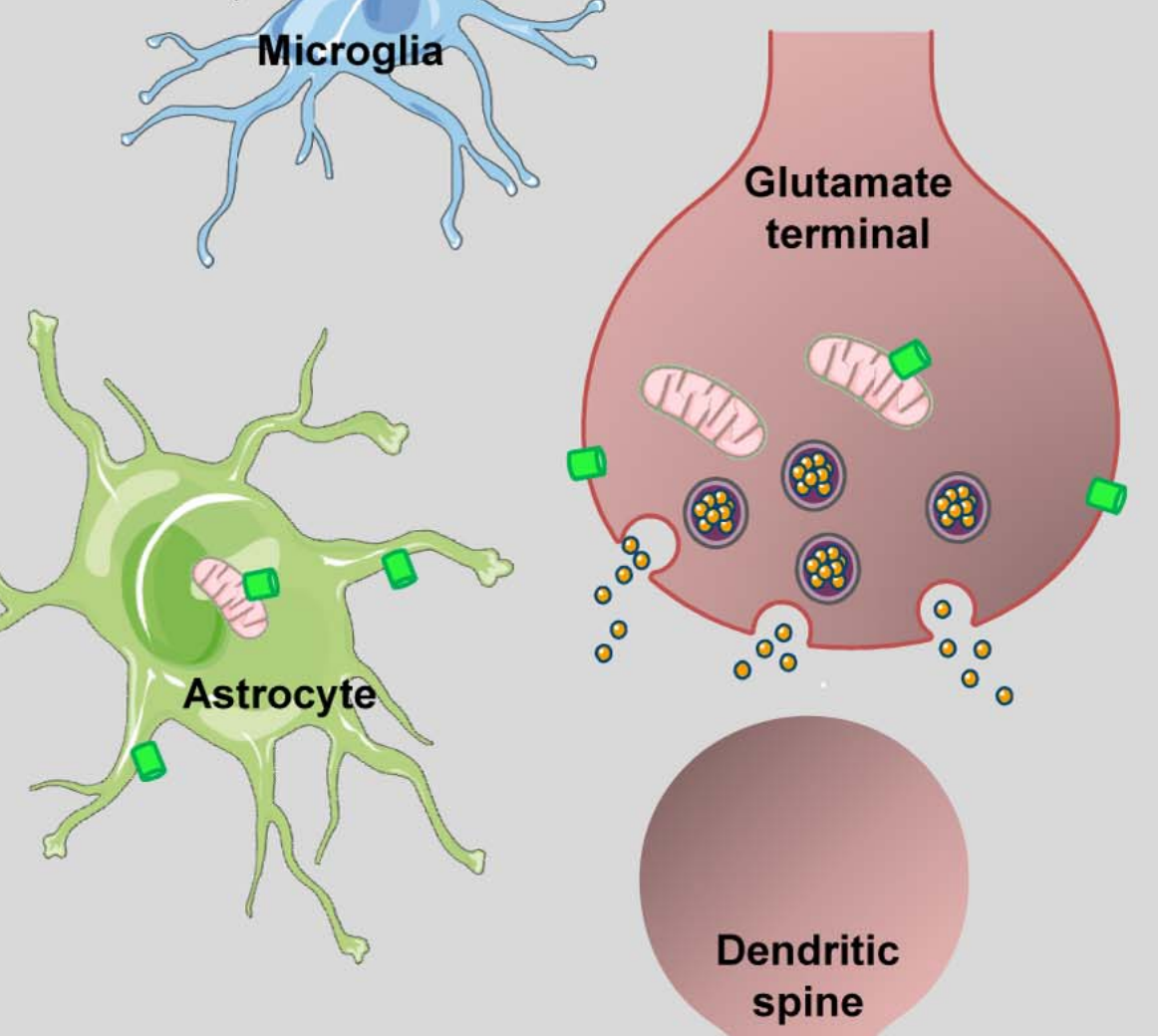

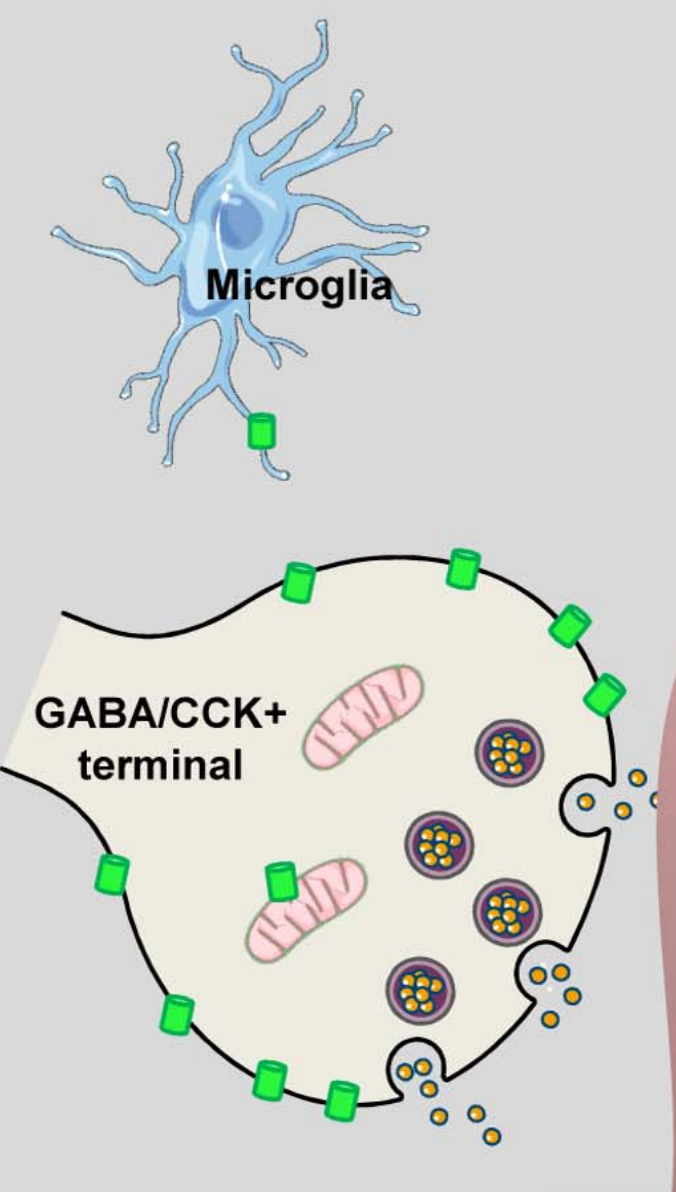

\section{Dendrite}




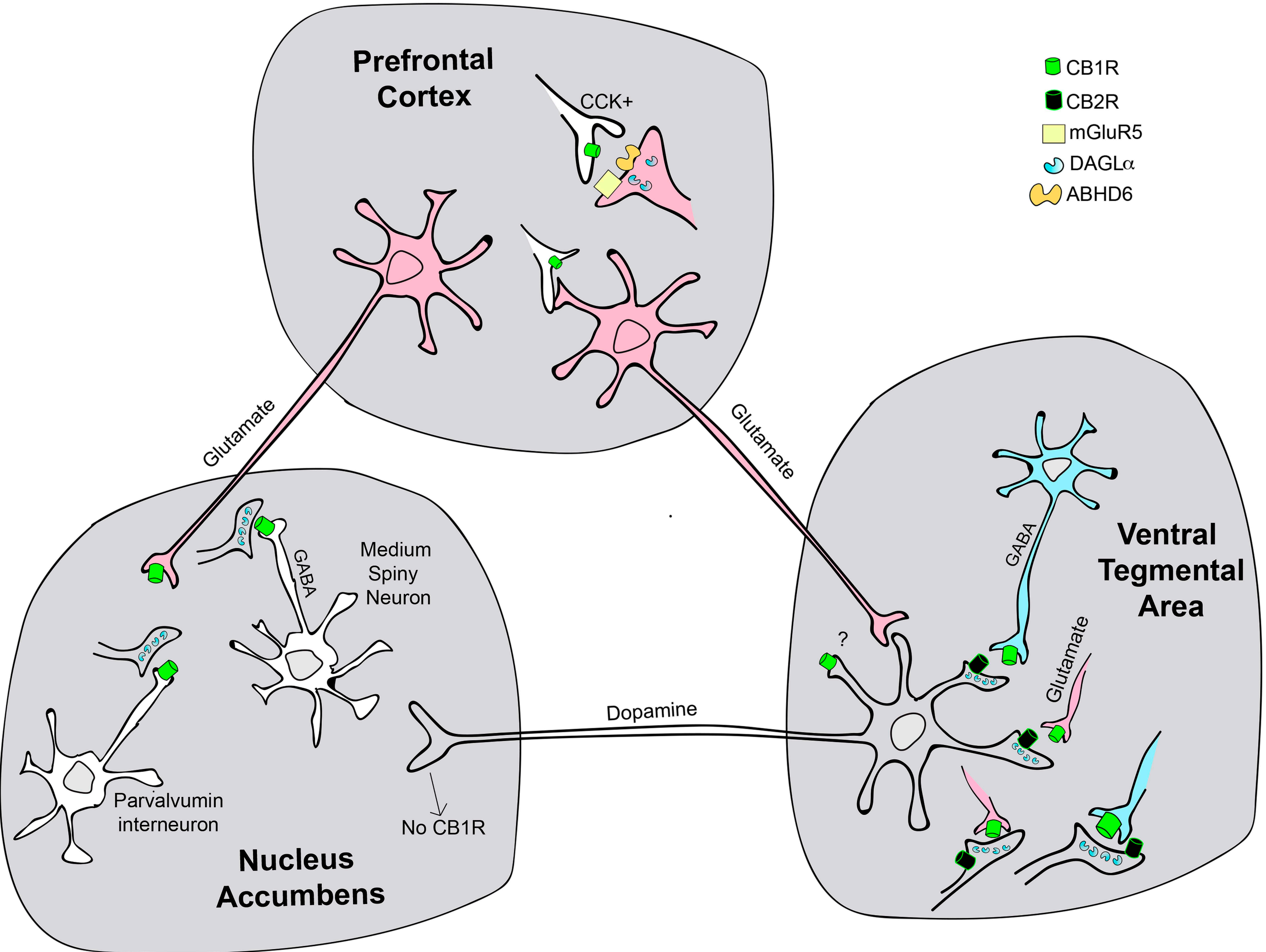


Table 1. Summary of results related with the involvement of $\mathrm{CB}_{2} \mathrm{r}$ on drug addiction

\begin{tabular}{|c|c|c|}
\hline & Evidences from pharmacological studies & $\begin{array}{llll}\begin{array}{l}\text { Evidences } \\
\text { genetically }\end{array} & \text { from } & \text { mice } & \text { modify } \\
\end{array}$ \\
\hline Cocaine & $\begin{array}{l}\text { The } \mathrm{CB}_{2} \mathrm{r} \text {-agonist JWH133 (systematic and intra- } \\
\mathrm{NAC} \text { infusion) blocked cocaine-enhanced } \\
\text { locomotion and inhibited intravenous cocaine self- } \\
\text { administration C57BL6/J mice[144]. } \\
\mathrm{CB}_{2} \mathrm{r} \text {-antagonist, AM630, reversed the cocaine- } \\
\text { induced alterations in cell proliferation including } \\
\text { neurogenic, apoptotic and gliosis processes in } \\
\text { Wistar rats [218]. } \\
\mathrm{CB}_{2} r \text {-antagonist, SR144528 reduced the } \\
\text { reinstatement of cocaine consumption in Wistar } \\
\text { rats [219]. } \\
\text { The CB } r \text {-antagonist AM630 failed to modify the } \\
\text { acute and chronic locomotor effects induced by } \\
\text { cocaine in Wistar rats [218]. } \\
\text { The blockade of CB }{ }_{2} r \text { did not modify contextual } \\
\text { memories associated with cocaine seeking release } \\
\text { in Wistar rats [219]. } \\
\text { Increased CB }{ }_{2} r \text { gene expression in mouse brain } \\
\text { preparations after repeated administration of } \\
\text { cocaine [77]. } \\
\text { Decreased CB }{ }_{2} r \text { protein expression in the } \\
\text { prefrontal cortex of Sprague-Dawley rats during } \\
\text { adolescence (PND33-39) after subchronic } \\
\text { administration of cocaine [220]. } \\
\text { Decreased CB }{ }_{2} r \text { immunoreactivity Lewis and } \\
\text { Fischer } 344 \text { rats exposed to cocaine self- } \\
\text { administration [221]. }\end{array}$ & $\begin{array}{l}\text { Transgenic CB2xP mice showed [140]: } \\
\text { - less motor response to acute } \\
\text { effects of cocaine. } \\
\text { - less vulnerable to the motor } \\
\text { sensitization induced by the } \\
\text { repeated administration of } \\
\text { cocaine. } \\
\text { - locaine induces place- } \\
\text { conditioned aversion. } \\
\text { - less acquisition of cocaine self- } \\
\text { administration. } \\
\text { CB2-/- mice showed: higher sensitivity } \\
\text { to the cocaine-induced motor effects } \\
\text { [217]. }\end{array}$ \\
\hline Alcohol & $\begin{array}{l}\text { The } \mathrm{CB}_{2} \mathrm{r} \text {-agonist beta-caryophyllene reduced } \\
\text { ethanol conditioned place preference and ethanol } \\
\text { consumption in C57BL6/J mice [223]. } \\
\text { The cannabinoid } \mathrm{CB}_{2} \text { r-agonist JWH015 increased } \\
\text { alcohol consumption in C57/BJ6 mice previously } \\
\text { exposed to chronic stress without [224]. } \\
\text { Downregulation of } \mathrm{CB}_{2} \mathrm{r} \text { in the Amy [226] and } \\
\text { striatum [227] of Wistar rats exposed to ethanol } \\
\text { withdrawal. }\end{array}$ & $\begin{array}{l}\text { CB2-/- mice showed: } \\
\text { - high vulnerability to the } \\
\text { physiological effects of a single } \\
\text { doses of ethanol [222]. } \\
\text { - increased voluntary ethanol } \\
\text { consumption in the two-bottle } \\
\text { paradigm [222]. } \\
\text { - increased motivation to drink in } \\
\text { the oral ethanol self- } \\
\text { administration [222]. } \\
\text { - increased alcohol drinking in the } \\
\text { intermittent forced drinking } \\
\text { paradigm under group-housing } \\
\text { conditions [225]. }\end{array}$ \\
\hline Nicotine & $\begin{array}{l}\text { The } \mathrm{CB}_{2} \mathrm{r} \text {-antagonist } \mathrm{AM} 630 \text { blockade nicotine } \\
\text { withdrawal syndrome in CD1 mice [228]. } \\
\text { The } \mathrm{CB}_{2} \mathrm{r} \text {-agonist O-1966 given in combination with } \\
\text { nicotine induced conditioned place preference } \\
\text { [230]. } \\
\text { AM630 did not induce any effects in Long Evans } \\
\text { rats [229]. }\end{array}$ & $\begin{array}{l}\text { CB2-/- mice showed [228]: } \\
\text { - no nicotine conditioned place } \\
\text { preference } \\
\text { - no nicotine self-administration. } \\
\text { - less somatic signs associated } \\
\text { with nicotine withdrawal. }\end{array}$ \\
\hline
\end{tabular}

